S H

167

$.517 G 5$ 


$$
\text { \% }
$$




\section{THE SALMON OF THE YUKON RIVER : : : : : :}

: : : : : : : : : : : : : : : By Charles H. Gilbert

From BULLETIN OF THE BUREAU OF FISHERIES, Volume XXXVIII, 1921-22 Document No. $928:::::::::$ : : Issued November 21, 1922 Dochent No.

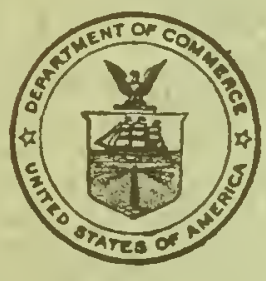

PRICE; 20 CENTS

Sold oaly by the Superintendent of Documents, Government Prinilag Odece; Waphington, D.C.

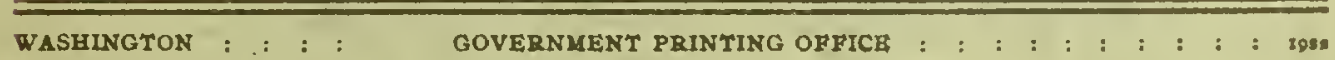



THE SALMON OF THE YUKON RIVER : : : : : : : : : : : : : : : : : : : : By Charles H. Gilbert

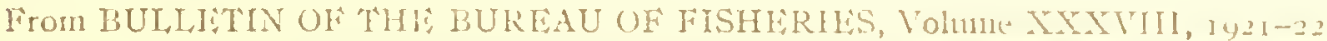
Document No. $928 \quad: \quad: \quad: \quad: \quad: \quad: \quad: \quad: \quad:$ Issued lioiember $2 I$, IQ22

20

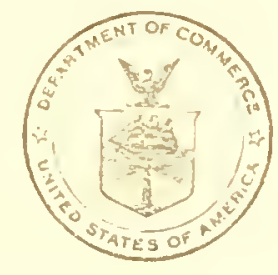

DRICE, 20 CENTS

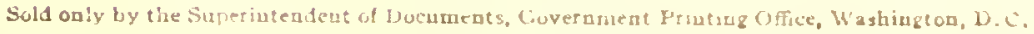




$$
5+14^{67} 4^{5}
$$

\footnotetext{
LIBIARY OF CONGRESS : =CEIVE:

IAN $241: 1 ?$ DOCUMLNTŚ RIVISION
} 


\title{
THE SALMON OF THE YUKON RIVER.
}

\author{
4 \\ 13y CHARI.WS 11. CHIMER't, \\ Profensor of Zooloul, Stamfond Cinizersity.
}

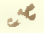

CONTENTS.

Intrudnetion

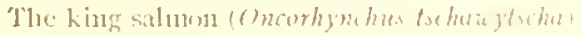

Ratc of tritrel

Growth and age at maturity

The clumm or derg salnon (Oncorhynelues ketel)

Rate of travel.

Year classies.

Proportions of sexes

Size at miturity

Growth :mel seale rearlings

The sockeye salnum (Oncomhynchus nerlin)

Tlue coho sitmon (Oncorh puchus kiruti i)

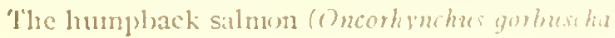

\section{INTRODUCTION.}

The summer of 1920 was spent ly the writer, in complany with Ilenry ()'Nalley, at that line ficld assistant of the Inited states linrean of fisherice, in investigating the 1 uns of salmon to the Jukon kiver. The primary ols ject of the expedition was to astertinin the advisability of pernitting the operation of one or more salmon canneries on the Juhom, in riew of the possibility that they night so curtail the salmon supply that it wonld fail to provide natives, and white inhabitants as well, with the stores of lish that lloy find essential under the rigonous conditions of the far northern clinate. It was to be determined whether there existed an excess above the needs of the inlablsitants that conld

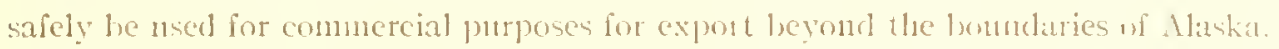

This pluase of the situation has been dealt with in a rejurt to the Commissioner of Irislacries and was pulblished in $1923 .^{1}$ Sone of the details that are given in that repont concerning the movements of the salmon during their run and the rate of travel that they maintain in their ascent of the river are herein repeated, but the body of the prescint paper is concened with the growth-history of the lonkon salnon and the ages at which they have reached maturity. The Tuhom River is near the nom them linit of range for the Pacific salnon. 'The eflect of the aretic cold on growth and age of maturing is ast interesting problem.

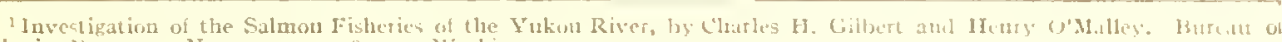

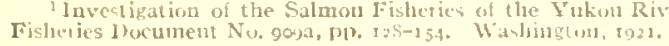


Three of the five species of salmon that occur along the Pacific shores of North America enter the Jukon Basin in sufficient numbers to constitute distinct runs. These are the king or chinook salmon, the chum or dog salmon, and the coho or silver salmon. the names here given are those by which these species are known in other districts of Alaska and generally along the coast to the southward. Unfortunately, in the Jukour Basith, there is confusion in this regard. The colno or silver salmon is most frequently called chinook, while the various grades of the chum or clog salmon are known as "silicrs," "half-breds," and "logs." The king salmon alone, of the three species that ascend the river in numbers, is called by the same nane by which it is elsewhere designated.

The two remaining species of Pacific coast salmon, the lumpback and the sockeye or red samon, enter the river each year in sunal numlers and have no economic importance. To what extent the individuals of these species may le strays from other streans that have well-defined runs has not been determined.

The material on which the present paper is based was obtained from June 15 to July 31,1920 , at the cannery of the Carlisie Packing Co., located in the entrance to Kwiguk Channel, a branch of the Kwikluak or South Mouth of the Yukon.

\section{THE KING SALMON (Oncorhynchus tschawytscha).}

The king salmon is the most highly prized for human consumption of the three Yukon species. It is also valued for dog feed, especially in the upper course of the river, for by the time the salmon have fought their way upstream a thousand miles or more even the richest species contains no more oil than is needed to furnish satisfactory dog feed. As it enters the month of the river, the Yukon king is the richest salmon known to us. It there drips oil profusely when hung on the racks to dry and is, in fact, too rich for most successful canning. The canned product, if handled roughly, or if shipped to distant points, is in danger of breaking down to a substance of mushlike consistency. King salmon taken at some point higher up the river, where a portion of the oil would have been expended during the ascent, would in this respect furnish a better commercial product.

\section{RATE OF TRAVEL.}

The run begins at the mouth of the river in the latter part of May or early in June, alnost as soon as the river is clear of ice after the spring break-11p; and it lasts as a commercially valuable run for about three weeks. Tradition has it the king salmon appear at points as high as Tanana and the Ramparts at the same time as the first steamer that ascends the river from St. Michaels on the opening of navigation. This would indicate an morecedentedly high rate of travel in a river with very swift current. Stch inconplete data as we have concerning the ascent of salmon in other rivers indicate a rate not to exceed to to 20 miles per day. But in the Vukon Basin the distances to be traversed are great-some of the spawning beds being 2,000 to 3,000 miles from the sea-and the summer season is much shorter than in any other large salmon river. These two factors necessitate a high rate of speed in ascending the river, and the fact that this has been developed in the Irukon salmon is one more instance of cluse adaptation to the conditions of their environment on the part of a highly localized race. Rapid ascent of a river means expenditure of energy out of all proportion to the distance to be traversed. Unttstal stores of potential energy in the form of oil are therefore required by the Yukon salmon. We have alreaty referred to the unusually rich provision of oil in the case of the king 
salmon, and the sane is true of the clum or dour salnon of the Vukon, which excels in richness and amount of oil the chum salmun from all other rivers in as great a degree as that which distinguishes the Yukon kinge from other king silnum.

As regards the rate at which they atemel the river, we liave more reliable and complete data for the Lukon than have heen secured in any other strean. Recurts were ohtained of their first alpearance at a large number of he: lities. Some of these were ascutained hy: means of wireless messages sent during the early days of the rum, before the dates of the first capiures shonkl be forgotten. Many others were ultained during our ascent of the river in early August, when all fishing canl]s were visiterl and reourds were inspected concerning the run of the summer. In a mumber if instance's complete written recorts were available, which gave not only the date on whic: he first captures were made, but the numbers of fish taken on each day of the season. II Trite we recognize that the capture of the firt

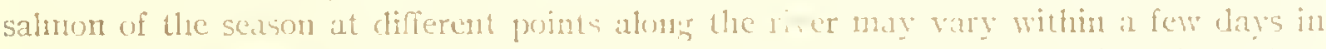
relation to the beginning of the rmm, we are combinced from an examination of our datiz that this sonece of crros is not serime ant that reliable conclusions concernivis rate of travel can be drawn from the table ( 1 ) presented below. 11 henerer two or more records

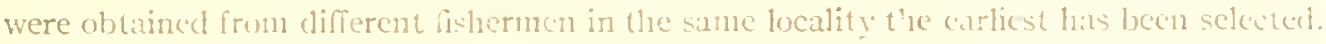

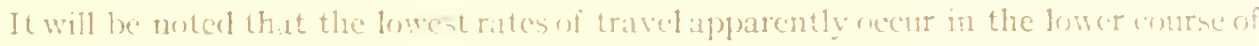

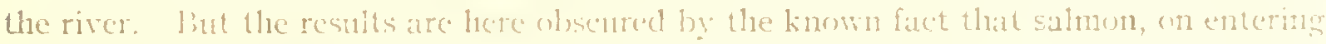

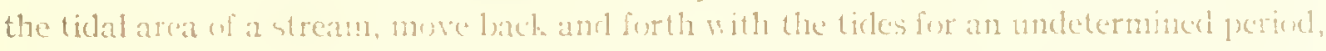
before serionsly undertaling the ascent of the river. "The intlucnece of this lacter, however, will nut alfune suffece tu explain the constant increase in rate of tratselas fint uy the

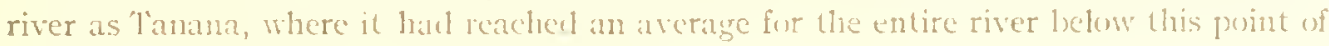
62 miles per dlay over a periokl of 1.3 diags.

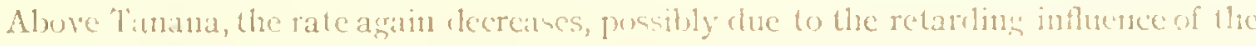

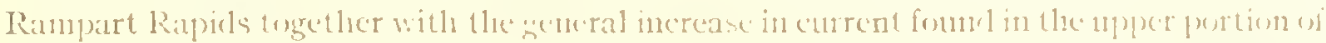

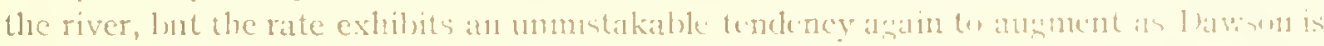

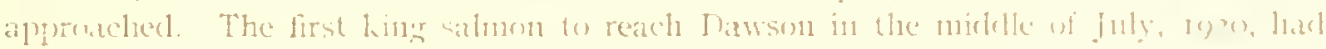

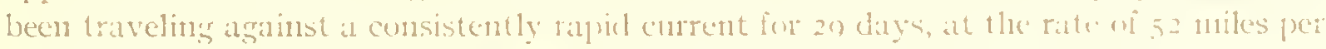

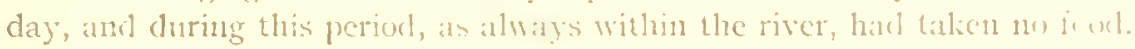

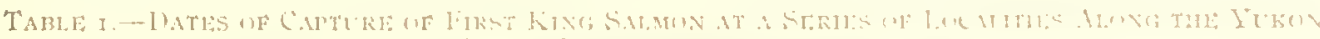
RIVLR DERIXYG SF.ASTI OF IQ20

\begin{tabular}{|c|c|c|c|c|c|c|c|}
\hline Lucality & Date. & $\begin{array}{l}\text { Amproxi- } \\
\text { nuste } \\
\text { numbluer } \\
\text { of mimles } \\
\text { iravelest. }\end{array}$ & $\begin{array}{l}\text { Mules } \\
\text { travelest } \\
\text { per dats. }\end{array}$ & 1.0uality. & [1..te. & 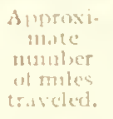 & $\begin{array}{l}\text { Me les } \\
\text { traveled } \\
\text { per alat. }\end{array}$ \\
\hline 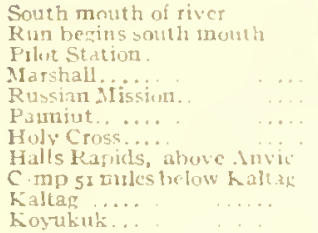 & $\begin{array}{l}\text { lune } 1 \text {. } \\
\text { June in } \\
\text { June } 20 \\
\text { fo.... } \\
\text { June } 21 \\
\text { June } 22 \\
\text { June } 23 \\
\text { June } 24 \\
\text { June } 27 \\
\text { June } 28 \\
\text { Juve } 20\end{array}$ & $\begin{array}{l}107 \\
1.44 \\
204 \\
250 \\
207 \\
2.50 \\
1101 \\
401 \\
555\end{array}$ & $\begin{array}{c}1 \\
2 \\
1 \\
-1 \\
\vdots 5 \\
1 \\
\vdots 1 \\
48 \\
40\end{array}$ & 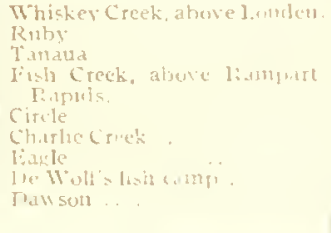 & 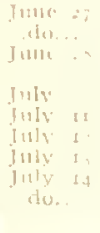 & 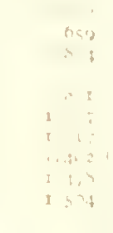 & \\
\hline
\end{tabular}

The season of 1920 was nutably late in Alaska; tlic brealk-up occurted in the Yuton fully a week later than usual, and the salmon were equally deluyed in entering. As shown by the above table, the first king salmun taken in the delta was captured Jume I3. 
The run culminated quickly within a week after that date, then maintained itself at a fair level for about three weeks, and was practicaliy over by the close of the first week in July. Stragglers appeared during subsequent weeks in July and August but became less and less numerous.

\section{GROWTH AND AGE AT MATURITY.}

We liave no knowledge concerning the feeding grounds of the Yukon salmon and numst leave the question open to what extent, if at all, the young traverse the passes in the Aleutian Chain and attain their growth in the North Pacific. It is entirely possible that throughnut their life in the ocean, they remain within the confines of the Bering Sea. None of them have been detected traversing the channels between the Alentian Islands, nor have they been recognized elsewhere along lines of their migration rontes in the sea.

Conditions in Bering Sea, it would seem, must be less favoralble for rapid growth tlian in districts farther south. The northern part of the sea and a strip around the coasts, including Bristol Bay, are covered with ice floe during the winter and early spring months. The temperatures to which the salnion are then exposed 1nust be near the freezing point. At the time they seek the river mouth in May or June the surface temperature in Bering Sea approaches $40^{\circ}$ F. Under such adverse conditions growth during the winter season must be at or near a staudstill and in the spring might well not be resumed before the beginning of the streamward migration. In that event the scales would exhibit no growth accomplished during the year in which the fish was captured. A salmon in its fifth year would indicate in its scale structure the completion of four full years' growth, and the margin of the scale would be forner by the winter check of the fourth year. In other districts to the sonthward the salmon of the spawning run have already responded to spring conditions and have begun a period of rapid growth before entering the streams. The scales have participated in this renewed growth, and the margins exhibit a larger or smaller band of widely spaced rings, which lie ontside the winter clieck of the previous year. But in the case of the Yukon king salmon this is not present. The winter cleck of the previous year forms the margin, and nsually no trace exists of any growth belonging to the current year. A very few cases forn doubtful exceptions to this generalization, with the onter one to three rings nuore widely separated at least in a portion of their course. This feature is shown distinctly in the accompanying series of plotographs of the scales of Yukon king salmon, ranging from those in their third to those in their seventh year (Iiigs. 276 to $2 S_{5}$ ).

Another striking peculiarity of the Yukon king salmon is found in their early history as fry and fingerlings. We did not secure any of the young, although attempts were made to capture them with minnow seines on their downyard migration, near the mouth of the river. But the central areas of the adult scales contain records of the early history and show conclusively in every instance that the young remained in fresl water for a full year's growth before descending to the sea. In the photograplss that follow, the linie " $I$ " points to the outer margin of the streain growth, which presents a nucleus of finely crowded lines, beyond which are the widely spaced lines indicating rapid growth after reaching the sea.

This habit of the Yukon lings is in striking contrast to what is observed in streans farther south. In the Fraser River, the Columbia, the Klamath, the Sacramento, and 
all other streams thus far examined it consideralse proportion of the adult s.llun are

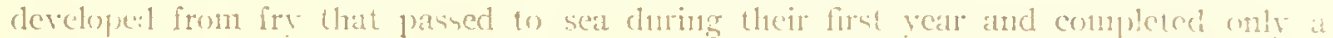
small portion of their hirst year's growth in irew water. "This "sea type" elevelups at an earlier age than do these that tarry a vear in fresil water, and it frequenthy. constitutes half or mote than half the entire run. "The absence of the "sea trpe" in the linkon mity well be related to the severity of the fall and winter, the latenese of the spring, anct the shortness of the smmuner season. It womld serent that the hatching of the eggs, the alsorplion of the yolk, and the eneroctece of the fry from the gravelis must be correspondingly retarded.

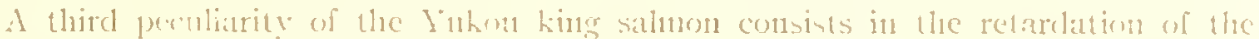
atre at which they attain maturity. In the Cofumblat River, where, owing to the noe of

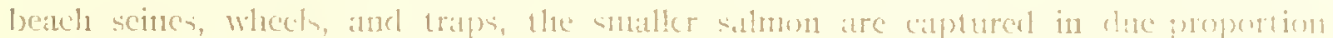

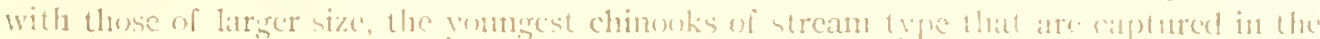

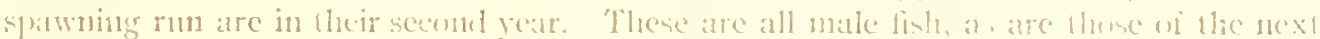

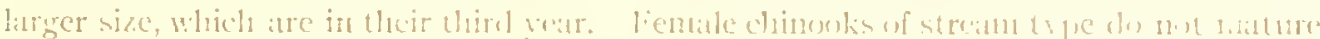

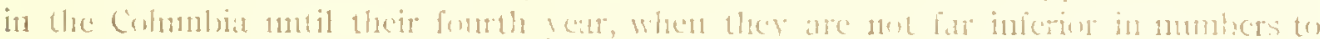

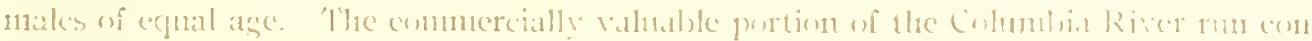

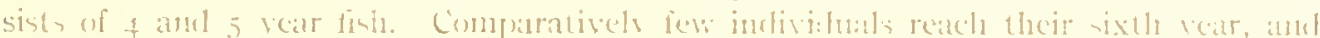

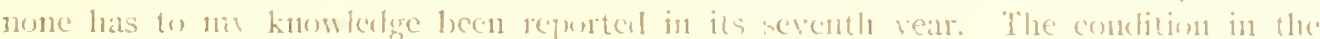

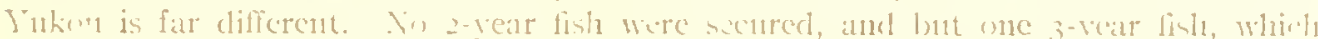
was a male, ot inches long, the seale of which is represented in ligutere z-o.

Fu spite of the fact that lishing was prosenterl exchuively by aill nets, which

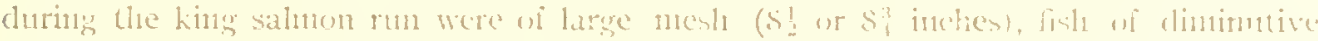
size we frequently entangled in the web and eaptures. Speciul attemtinn was patil

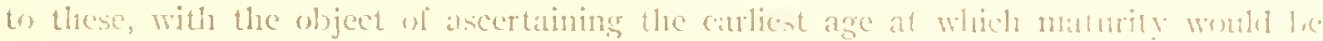

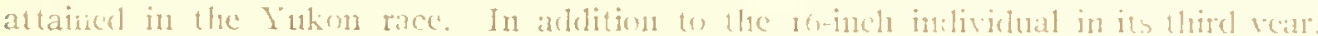

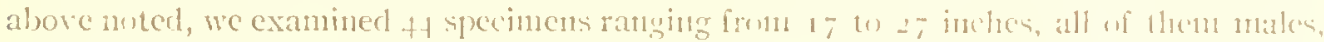

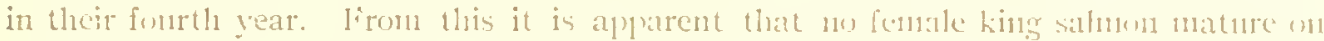

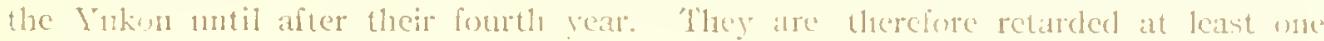
year in reaching maturity, as conpared with king sinnon in the nure sonthen part of the range of the species. (See fings. 277 and 278 .)

Continuing the examination of larger sizes we enconntered the first 5 -roin mak at 25 ituches, the males of this age ranging from 25 to th inches. In the fifth vatr, foi the first time, we enconstered female salmusn, but these were very iow in inmber. Anong the 1.31 individnals in their fifth year that we have examined, selecterl wholly

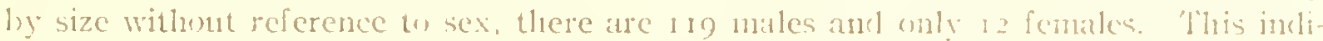
cates a still further retardation in age of maturing of females. Not (mil are there 13 ) f-year muture females (so) abundant in unre temparate lititurles), lut comparatively few females develop matmity even at the are of 5 . The 12 of which we have record lie in size within the range of the 5 -yent males, the smallest being 30 and the largest 37

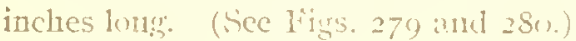

The male o-year fish are numerous, the 79 individuals representerl in our serics ranging widely from 27 to fin inches. There is thus a wide overlap in size between the 5 and the 6 year fish, as is always the case, although, as will he noted, the + and the 5 year males slow but little overlap. Anong the f-year fish, for the first tinne, fontalen, 
are rcally abundant, exceeding in number the males of equal age. Of the 185 6-year individuals, selected without reference to sex, 79 are males and 106 females. (See Figs. $2 S_{1}$ to 283.$)$

Another evidence of retarded development is found in the class of 7 -year fish. In streams thus far studied from the Sacramento to the Firaser it is very rare for a king salmon to attain the age of 7 years. Cnly two such specimens have been observed to my knowledge. In the lukou, however, nembers of this class are not uncommon. Althougln not specially sought for, 42 are included in our scries, io of these being males and 32 females. Here, again, the late development of females compared with males is made evident. (See ligss. $28+$ and 285 .)

Table 2 gives the distribution by sex, age, and lengtl of all the king salmon of our Iukon series of the run of 1920 . For comparison similat data from a series taken from the run of 1919 by C. F. Townscucl, fisheries inspector for the Bureau of Fisheries, are included in this table. It should be noted that the relative size of these various classes in our series does not represent thcir relative abunlance in the run. While no selection was made by sex, frequent selection mas madc by size at critical points. Thus, special attention was paid to the smaller sizes, and these appear in our series in more than their wormal proportions. The same is true of individuals approximating 30 inches in length. It was at this size that fenales first were fonth, and individuals of this length were specially selected for examination.

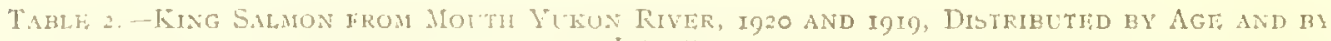
LENGTH.

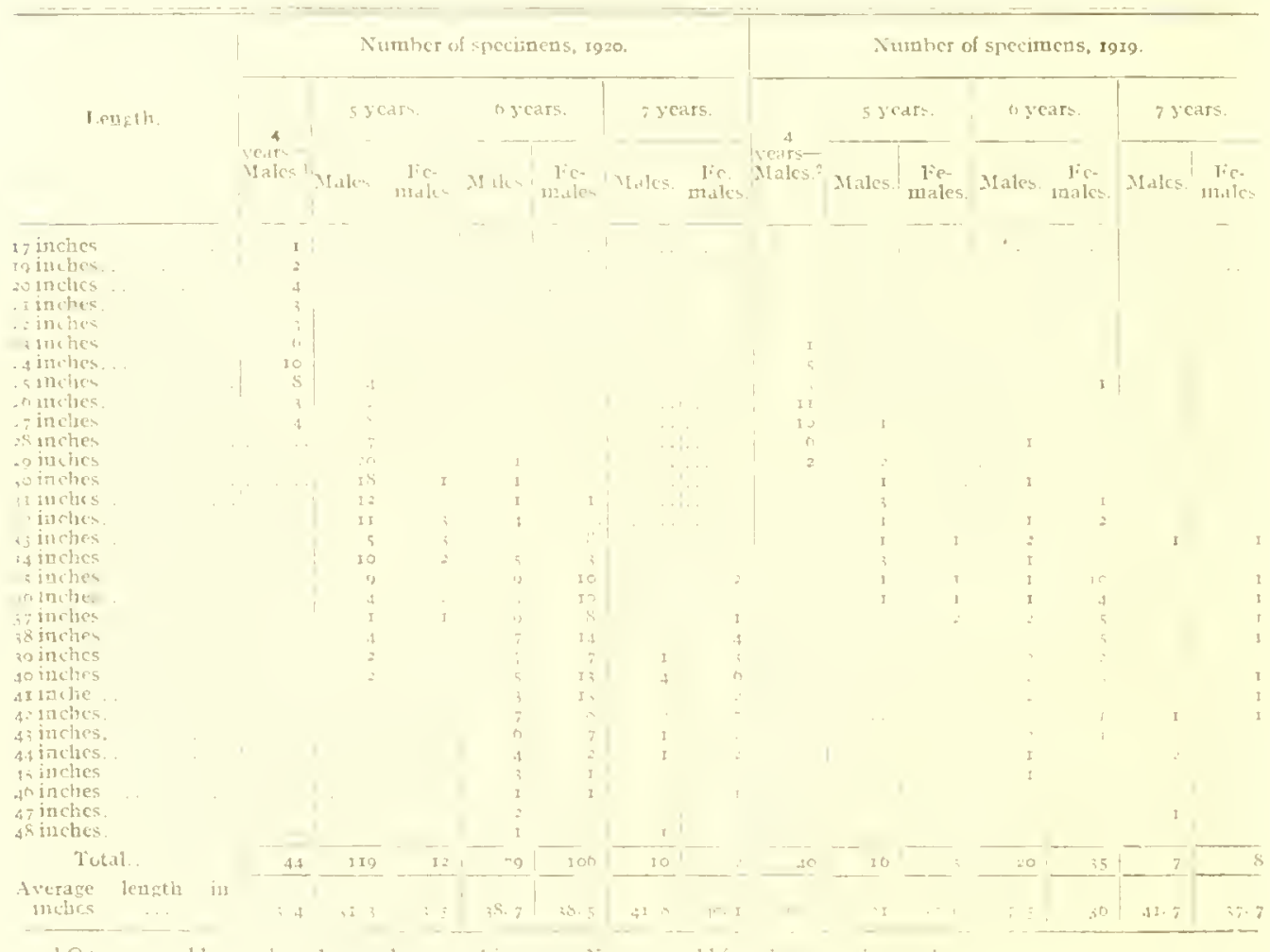

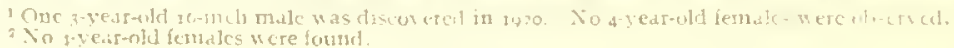




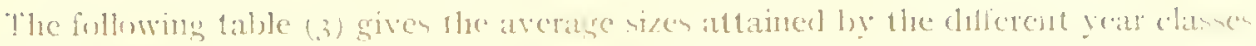

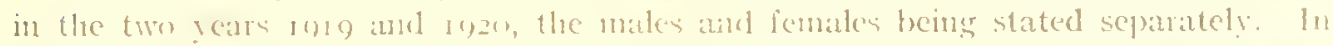

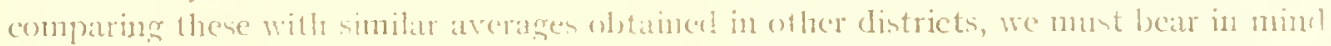

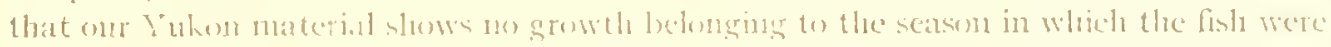

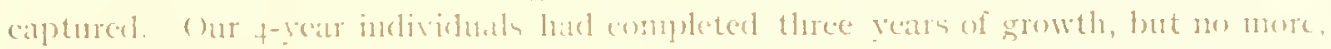

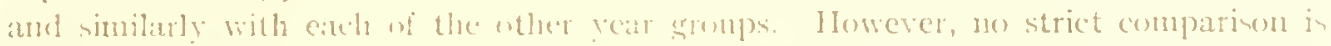

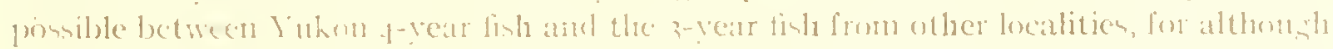

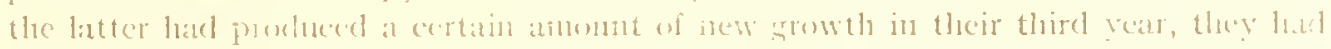
not completed the wrowth of the third reat whes they ceased feedise and were (atp)

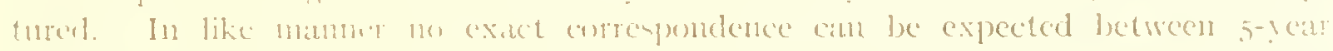

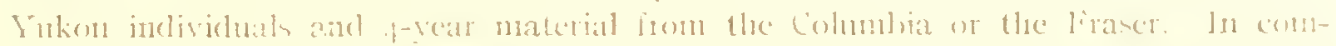

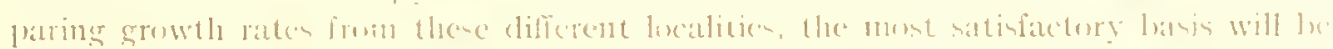

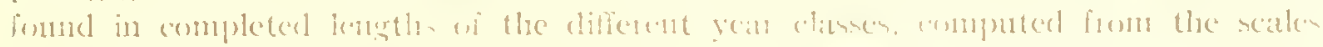

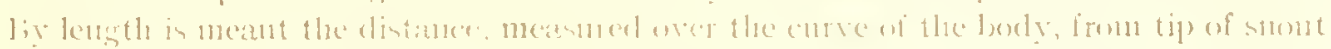

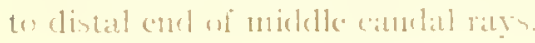

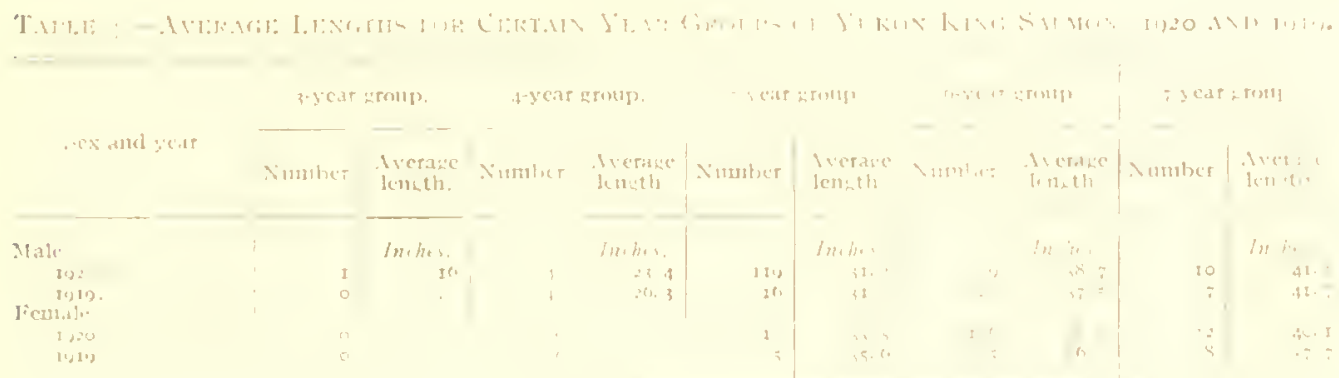

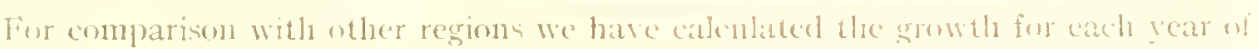

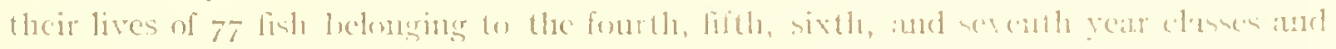

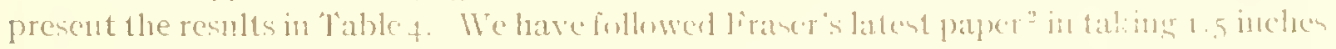

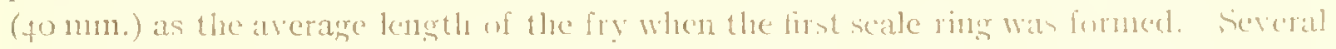

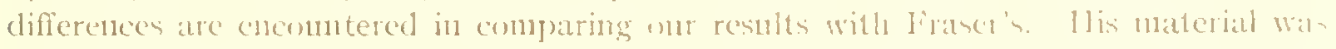
largely taken in the Gulf of Ceorgia and included an mixtme of linh that would matume during the dhen current season with others that womkl delay natming for one w more years; also, coubtless, a mixtunc of races, bundel for different river basins and unlike int

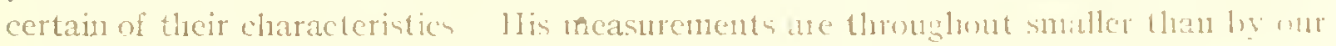
method, inasmuch as they he mot inelude the leneth w the midelle conclat rays.

Table 4, which follows, showe with regard to cateh year clasis that the growth rimsintr

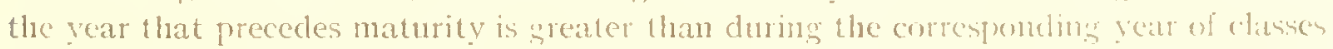

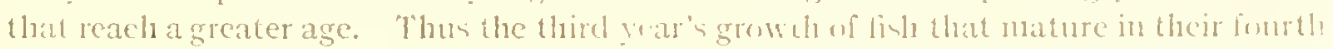

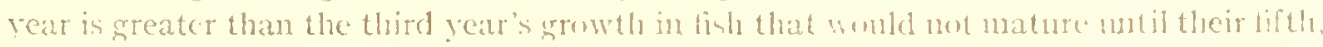
sixth, or seventh years. linrthermore, it is greater in s than in 1 year finh and greater in individuals that mature in their sixth than in those that mature in their wenth yeat The third-year growths form a regularly ascending serien from 7.3 indes in the olicul year class to I $2 .+$ inches in the youmgest, and the lengths of the fish at the end of thein third year form a similar advancinr series. According to this table we slombl find that the largest series of $3-$ gear fish in the soa at any time is composed of those inclividuals that will carliest mature. The same is true wi the errowth of the fourth year

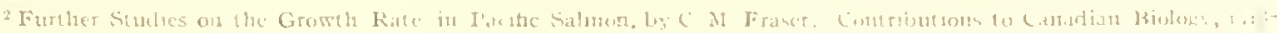

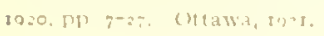


and of the fifth. Slow growth and smaller size mean deferred maturity in all vears cxecpt the first and the second.

The failure of similar results to appear in Doetor liraser's article, above seferred to, may be due to the mixed nature of his material. His seconc, third, and fonrth year classes are not composed of fish maturing in their second, third, or fourth years, but are accidental assemblages of fish that were in their second, third, and fourth years at the time they came into his hands. His second-year class doubtless contained individuals that would eventually inature varionsly in their second, third, fonth, and fifth years; and his third-year cliss, fish that woukd mature in their third, fonth, and fifth years. Inder such conditions differential methods of growth of year classes could not be discnvered, even if they slould exist. In Doctor liraser's 1915 material it was indicater that the f-year fish that were preparing to spawn were larget than those of equal age that would remain in the sea for another year. 'That result was in harnouy witl onr present findings but was not verified by him in the material of 1916.

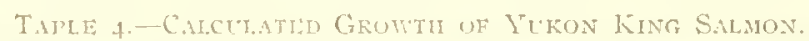

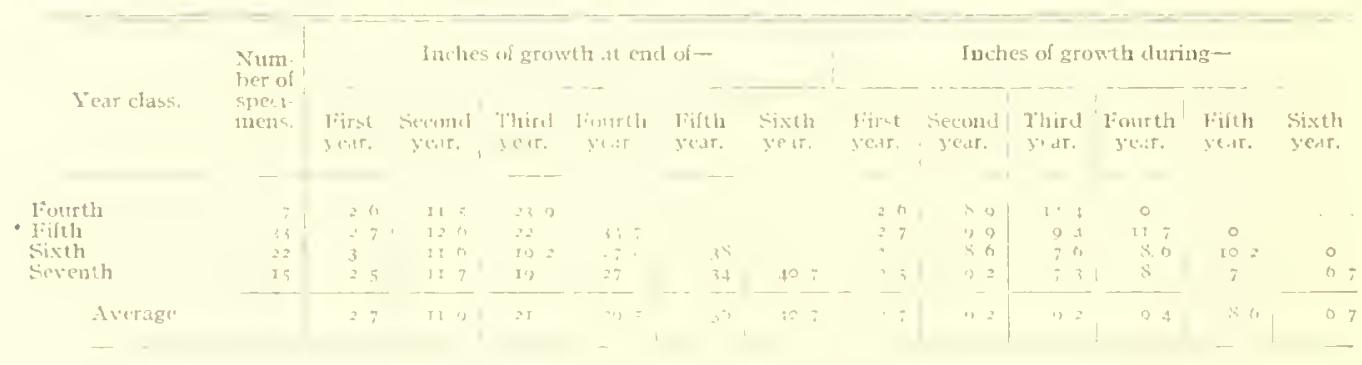

In the following table (.5) is given the arerage weight for all specinens of at given length, the mules and females being stated separately. The weights were taken wit' an ordinary spring-balance scales reading to pounds and half pounds. No ligh dropre of accuracy can be clained for this methor. but the resnlts present interesting terms of comparison with the king salum races of other rivers. The mumber of records arailable for cach length is insufficient for a wholly reliable average, a fact that will explain irregularities in progression in the table. It will be noted that fenales of equal lengti with males average stightly leavier than the latter. There was no noticeable elongation of the jaws in the males at the time this naterial was examined.

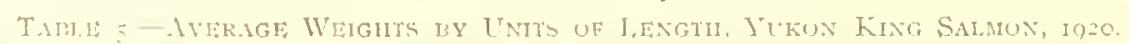

\begin{tabular}{|c|c|c|c|c|c|c|c|c|c|}
\hline \multirow[b]{2}{*}{ Ietigth. } & \multicolumn{2}{|c|}{ Miles. } & \multicolumn{2}{|c|}{ Fiemales. } & \multirow[b]{2}{*}{ I.cngth } & \multicolumn{2}{|c|}{ Males. } & \multicolumn{2}{|c|}{ Pensules. } \\
\hline & $\begin{array}{l}\text { Nonber } \\
\text { of speet- } \\
\text { mens }\end{array}$ & $\begin{array}{l}\text { Average } \\
\text { weight }\end{array}$ & $\begin{array}{l}\text { Average } \\
\text { wevishts }\end{array}$ & $\begin{array}{l}\text { Ninnhet } \\
\text { of socti- } \\
\text { miens. }\end{array}$ & & $\begin{array}{c}\text { Number } \\
\text { of speci- } \\
\text { niens. }\end{array}$ & $\begin{array}{l}\text { Averafe } \\
\text { weishts. }\end{array}$ & $\begin{array}{l}\text { Average } \\
\text { weughts. }\end{array}$ & $\begin{array}{l}\text { Nuruber } \\
\text { of speci- } \\
\text { mesti. }\end{array}$ \\
\hline If unches & 1 & Pand: & $P(n x, 2+1$ & & 3 inches. & 15 & $\begin{array}{r}\text { Perunds } \\
18.2\end{array}$ & Pindind: & \\
\hline I - iuches & I & 2 & & & 35 iuches. & 18 & 20.3 & 20.4 & $x^{4}$ \\
\hline$\therefore$ inches. & 4 & 4 & & & 36 inclues. & i & 21.7 & 22 & $I_{4}$ \\
\hline ariuches. & i & .1. 7 & & & 37 tuches. & 9 & 22.4 & 23.9 & II \\
\hline 22 inches.. & i & 5 & & & 3.4inches. & I0 & 25.2 & 20.3 & 59 \\
\hline - inclies. & is & $e, s$ & & & aninches. & is & 26.8 & 28 & I: \\
\hline tinches. & T. & 0. 1 & & & oinchrs. & 1: & 48 & 30.5 & 10 \\
\hline iuches. & II & $: 4$ & & & in nebes. & 1 & 31.2 & 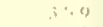 & te \\
\hline$\rightarrow$ iuches. & 5 & $\because .3$ & & & $4 \geq i$ ches. & $\theta$ & $360 .=$ & $3.4 \cdot 1$ & th \\
\hline ittlines. & 1 & 9.0 & & & 43 inches. & 7 & 35.9 & 18. 3 & 9 \\
\hline tuches. & 7 & 10. 1 & & & $4+1$ a ches. & 5 & $4 t .2$ & 4I. 8 & 4 \\
\hline sinches.. & i & If .3 & & & sribches. & 3 & 43.7 & $4^{2}$ & I \\
\hline onclies. & 19 & 12.0 & 11 & I & 40 incher. & 1 & . in & $4^{4} \cdot 5$ & 2 \\
\hline if inches. & 13 & 1.1 & is & I & 47 incues & 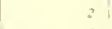 & in 5 & & \\
\hline rinches.. & 25 & $1 . \% .5$ & $7 \%$ & 3 & 4 inches. & 1 & 45 & & \\
\hline 33 inches.. & 5 & 113.4 & 17.1 & If & & & & & \\
\hline
\end{tabular}


The nuclear area of the seales of lukon king salmon is of extremely small suze and contains correspendingly few rings. Lndoubtedly this inlicates comparatively verve small size for the lingerlings at the time of their downard migration. Our table indieates an average size for migrating fingerlings of 23.4 inches. This is based on the assumption that the fro are 1 's inclies bin when the first scale ring is formed. If, as seems more probable, they are slightly longer than this, our computed lengths of mirating fingerlings whith be errespondingly increased but conld not much excred

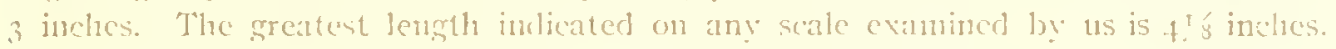
The number of nuclear rimss for cach year class is as follows:

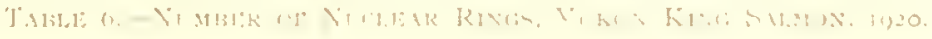

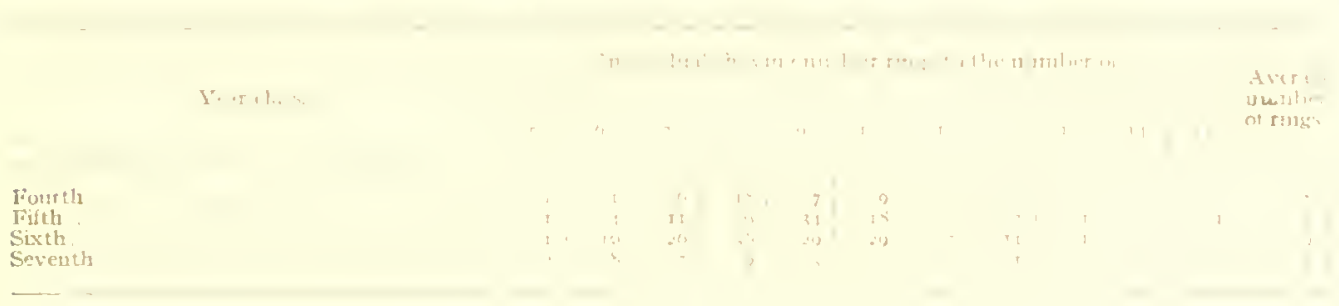

THE CHUM OR DOG SALMON, Oncoingnchus keta.

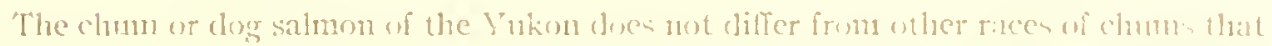
frequent streans in the more sonthem portion of its range either in external appearance or in any of the structural powliarities that distinstuish this species. As is the circe clecwhere, indivishals captured in the sea or those that enter streans well in advance ol the spawting perion are sytmuctrical silvery fish. casily mistaken at a crlance for the socheres salmon. The diseobration of the skin and the chryation withe jaws, whell are later

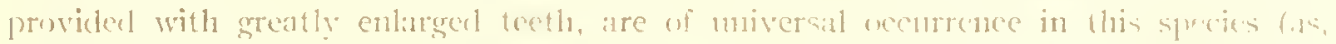

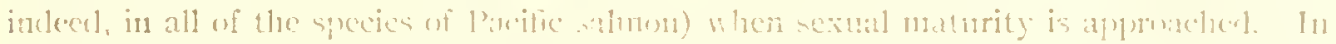

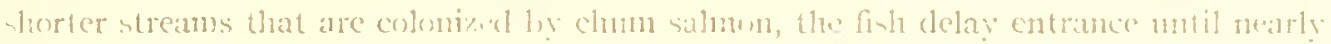
ripe and when first seen have alreaty lint their silvery livery. Hut in the Yulum, this:

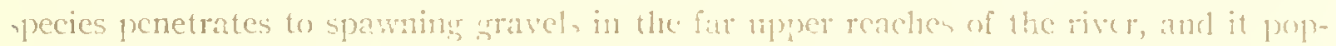
mates as well practically all the tribularies in the midlle and the lower course of the sirean. We fund, accordingly, anumg the chmme entering llae muth of the river al

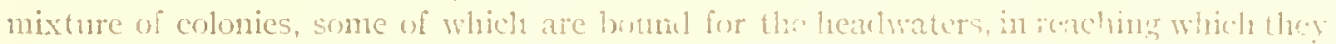
will spend six weeks or more, ard others that have not far to gro. it is mulomblecily for this reason that the entering fish vary su widely in different portions of the run in the extent of development of those striking clanacteristics that aconmpuny maturity.

Inring the season of 1020 all the early chuns were of bripht silvery onlon and lad alundant oil and a pinkish Resh tiut turnel a cleaper rel nu drying. but in a short time ehanges appeared, even at the nouth of the river. At first occasimal indisiduats, usually males, appeared in a more advanced stage, with brightly colored bars on the sicjes of the body and with long hooked jaws. When these were lirst observed they stood out conspicuonsly from their felloms, which were still in the "silver" stage. By the lant of

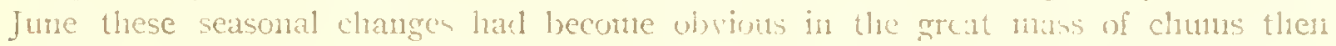
running. It was the rule for the males to exhibit elongated jaws, provided with canine teeth, and to show the besimings of the brigint ('oss-hats that dhatacterize the spawng

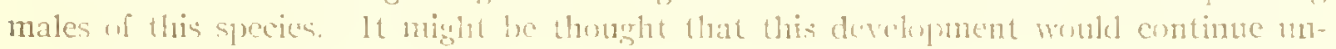


'liccked until the end of the season, but, strangcly, during the sccond week in July a: fresh run of chums that was no further advanced than were the chums of early Jine made its appearance. These also were of bright silvery color and had symmetrical jaws and abundant oil. Althougl entering relatively late, it seems safe to assume that this run was far from its spawning period and had far to go. Along all the lower and niddle portions of the river fishermen who prepare dried salmon for winter use distinguisln between the silvery chums and the other"s. The "silvers" lave llesh of brighter culor, rich in oil, and of more substance when dried. "Thle others are known as "dog salmon," with intermediate stages called "half-breeds," and are far inferior in value for" human consumption or as dog fecil.

The Yuton chums in their prime are doubtless of far ligher quality than clums from any other river. The differences between them and other races of clums are of similar nature to those that distinguish the Fraser River sockeyes from the sime species known as red salmon in the arerage illaska streams and to those that distinguish the chinow salmon of the (r)lumbia from the sume species ("king salmon") in the shortcr streams of the north. The differences in all these cases are mot only of similar nature, they are due to the same cause. The fine quality of Yukon chums, Fraser sockeyes, and Columbia chinooks is due to the great length of streann which they nust traverse. while fasting, on the way to their spawning grounds and to the large store of oil that they minst liny up for use at this time. In no other respects are the clninn salmon of the Vinton clifferent from the sane species fund elsewhere. The Yulun king sulmon, as we latve previously. noted, are characterized by the sane excessive povision of sil. They also exhibit in the different portions of the run equally striking differences between briglit individuals, relatively green as to eggs and milt, and the sextlally advanced forms, with hooked jaws and discolored skin. It would be no less logical to recugnize two or tiree kinds of king salmon than it is to distingnish, as is popularly done on the Vukon, two or three kinds of chums, according to the degree of their advancement toward spawning.

\section{RATE OF TRAVEL.}

The chum salmon is generally known as a species that spawns exclusively in the lower courses of streams, of ten seareely above the reach of the tides and never far from salt water. It is a remarkable reversal of habit in the Vukon chums that colonies of them should penetrate more than 2,000 miles to the upper tributaries of that great river; and it testilies to the flexibility of organization in salnon that a species that is in general not adapted to long journeys while fasing, can, under spur of necessity, make sucl journeys withont food and exhibit great speed and endurance. From recurds of the first appearance of chums at a large number of stations during the season of 1920 , it was apparent that their rate of travel was not far below thin of the powerful king salmon. They entered the river about a week later than the kings, at lanana they were not more than Io day's behind the latter, and at Dawson they were some 14 days behind the kings. 'The lower soo miles of the river, as far as Tamana, were traversed at the rate of 50 miles per day, and the next 700 miles, between Tanani and Dawson, were covered at the rate of 35 miles per day. The lower 1,500 miles were ascended at the rate of +2 miles per day.

\section{YEAR CLASSES.}

We have already noted that the king saimon of the Fukon are retarded in their levelopment and miture on the average more than une year later than the king salmon 
from southern waters. A similar retardation is obierved in chum salmon, which average distinctly older in the Jitkon than in any other region of which we have record.

The earliest report on the ages attained by this species and on the relative propottions of the year classes was based on a small collection taken at Jellingham, Wash., carly in August, I')10." The number investigated was t(w) small (.5 in all) to give reliable averages, but the percentages inclicated (h, not differ materially from those

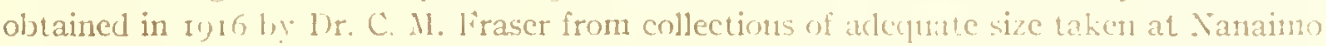
and Qualicum, in the ("ulf of Georgia. In both cases the majority of the elums were foumd maturing at the aye of 3 and 1 years, witl very few indivicluals at 5 years and an occasional rare specinen in its second year. Table 7 gives the results derived from

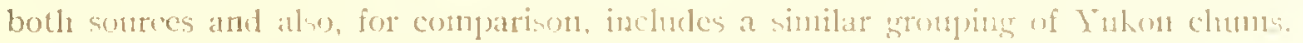

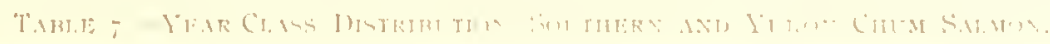

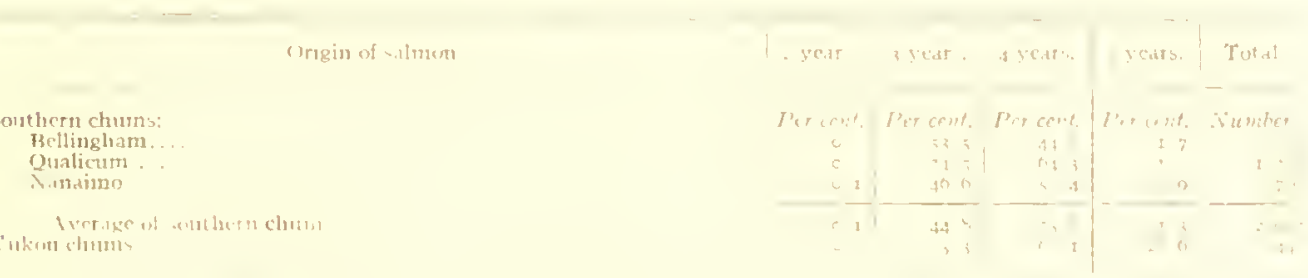

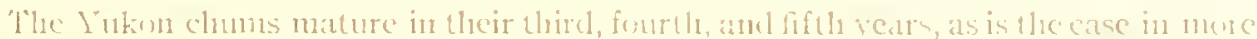

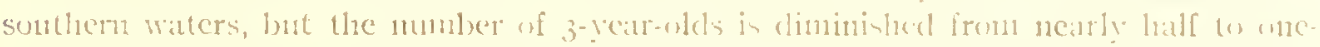
thirticth of the total number, and the 5 -year fible slow: a comenpondiner increase from 1

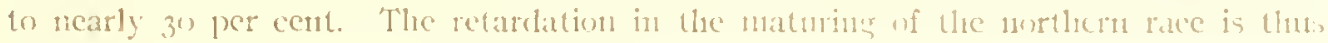
crivlent.

\section{PROPORTIONS OF SEXES.}

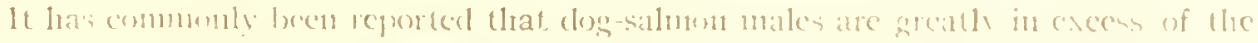

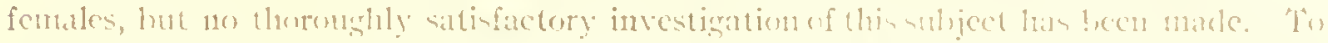

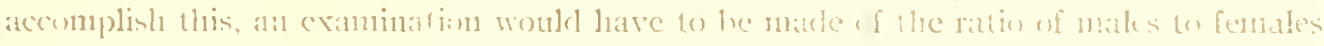
at ferquent intervale thronglont an entire rum. It might well he everected that the

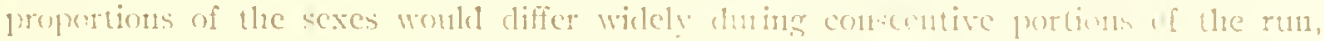

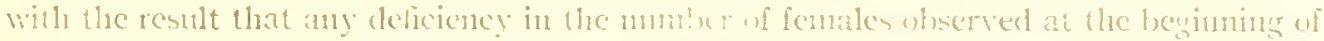
the rus would be compensated for by an exeen of fomalks hater ont. Such an werurrence has been repeatedly oberved in cortain srekeye colunies. Four-rear male soch. cyes cntering Rivers Inlet, British Columbia, in lo) \%, varierl from I(x) per" cent of the

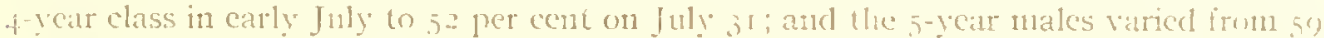
per cant of the 5-year gronp on July 10 to 23 per cent on July 31 . It is elear, therefore,

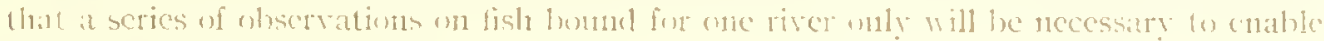
us to defernine this point.

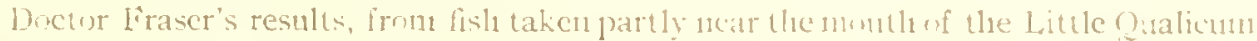
Jiver and partly from the vicinity of Nanaimo, agtee in showing from both districts an increased percentage of males in the older ycar classes. The percentages of males in the third, fourth, and fifth year classes in the Nankimo lot, range $42.6,02.1$, and Ino; in the Qualicum lot, $51,6.3 .8$, and $S 0, \ldots$. If these represented the average pereentages

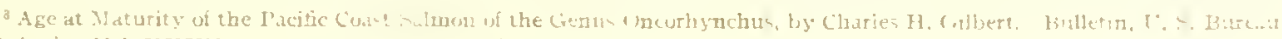

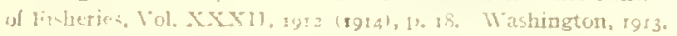


during the entire season we should have a considerable preponderance of males over fenales on the spawning beds and we should also have indicated a relatively earlier maturing of females than of males. Both of these rusi1ts wonld be unexpected. While tio deternination has been made of the ratio of the sexes in dog-salmon fry, analogy with other species of salmun would make it appear probable that males and females are in approximately equal numbers at the time of hatching. If this be true, a final excess of males in the spawning run could only be bronght about by selective mortality directed against the females. It dies nut secm probable that this exists. As regards an earlier maturing of the females than of the males, producing a heavier percentage of females in the yolnger groups, we can unl" note that this vould be the reverse of what occurs in king salmon, sockeves, and colios.

In the Dellingham nuaterial, previously referred to, we found 67 per cent males and 3.3 per cent females, the proportion of nuales and females being approximately the same in the thirsl and the fourth year groups. In Doctor Fraser's material, the totals showcd 5) per ecut males and ! per cent females.

The Yrikon specimens, fts in mumber, contained 57.6 per cent males and +2.1 per cent

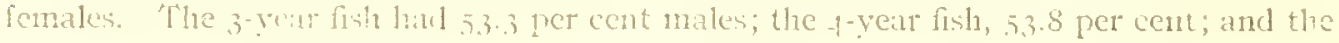
5-year lish 67 per rent.

\section{SIZE AT MATURITY.}

The length and weiglit frequencies are given in tables $S$ and '), which follow. 'These indicate nnmistakiably that the nurtheru race is retarded in its growtin and reaches a smaller size in each year class than is attained in Puget Sound and the Guli of Gerrgia by fish of equal age. To compare with the average lengths of Tukon chums, we repeat below those giren by Doctnr Fraser based on Qualicum and Nanaimo material. As measurements of the latter were talen only to the base of the middle caudal rays and our measurements include the length of the middle rays thenselves, we have adder $7^{T}$ ś per cent to Doctor Firaser's measurements to make them comparable.

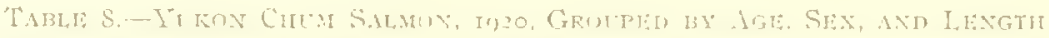

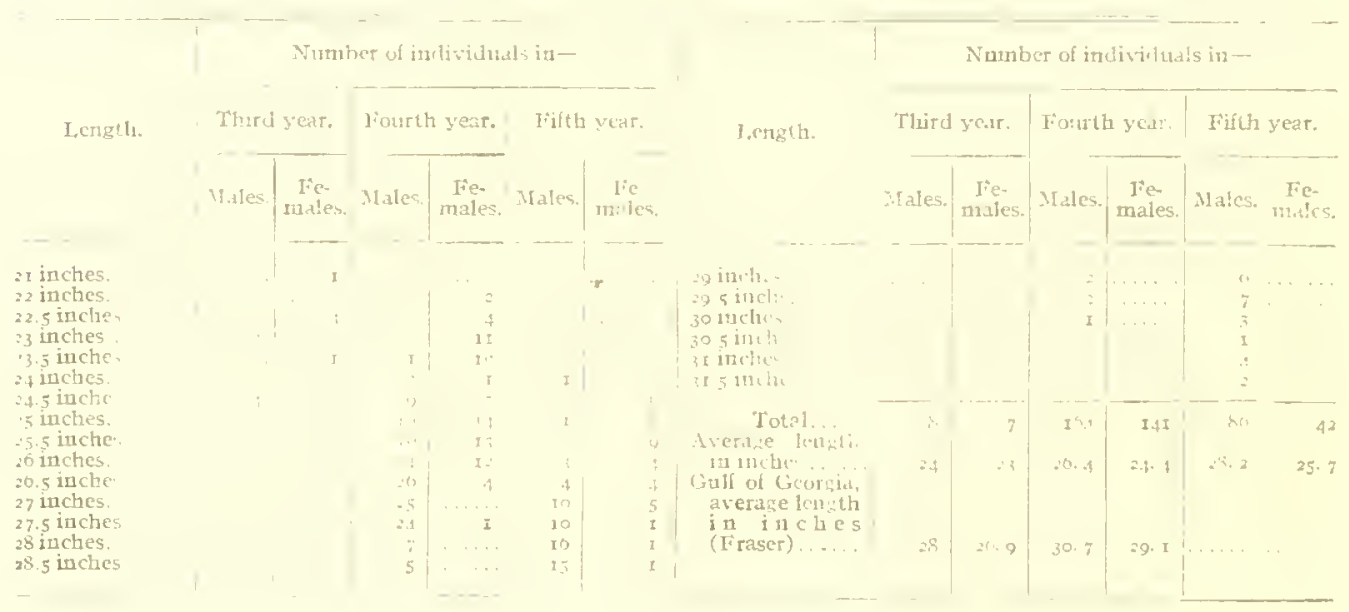




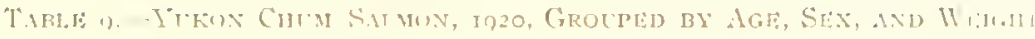

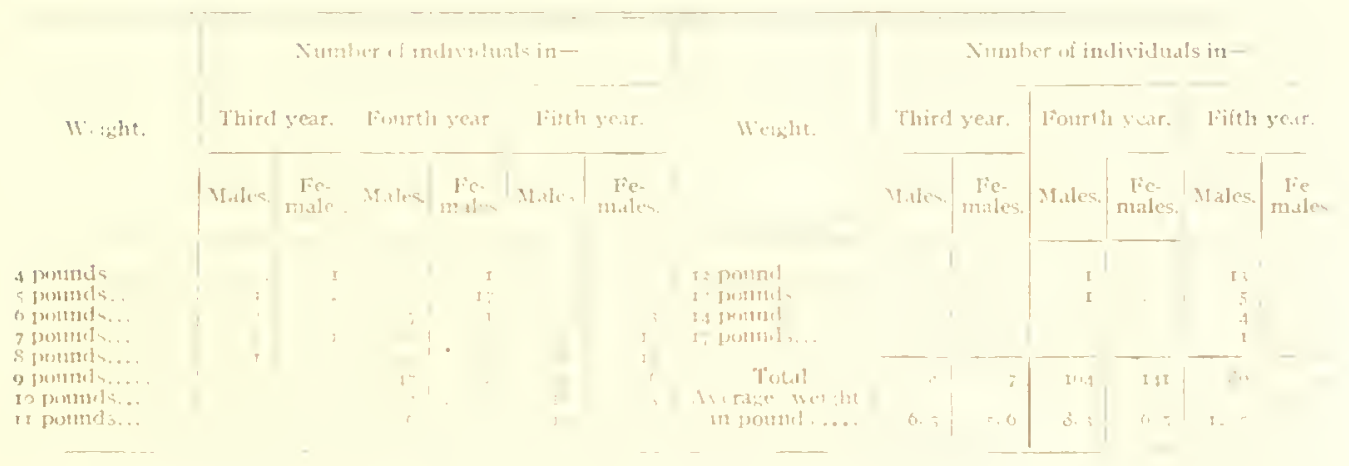

The length-weight relation lnip, indicated in finlle 10 , is given withont referente to age. The average weinht of all males ant, separtutely, of atl femalen that hare the same length is stated. According to this table, fentales arerage tightly lighter thatn matcs of

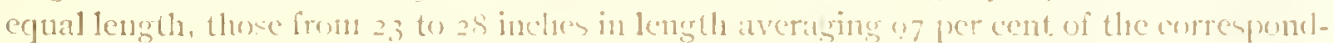

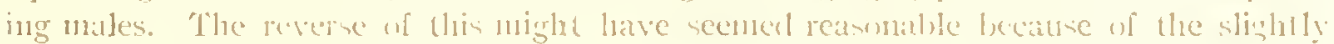
lengthened jaws in the milles.

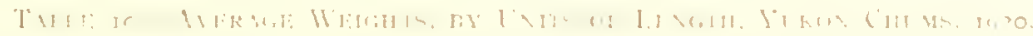

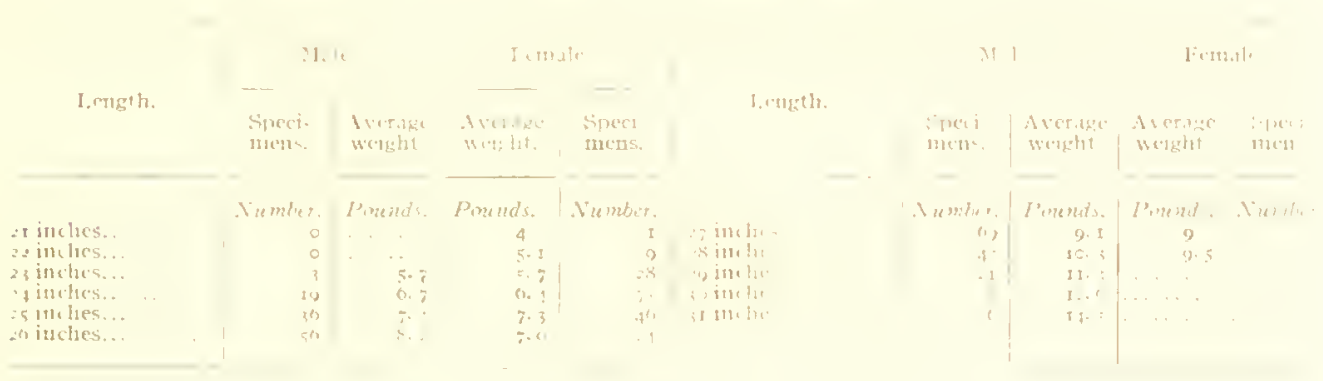

GROWTH AND SCALE READINGS.

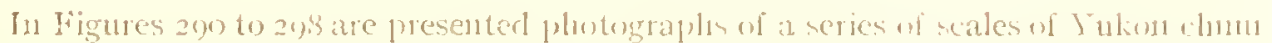
sulmon that include representitives of all the year clases fomm in enir collection. All of these agree in belonging th the scit type-that is, the scales were wholly formed in the sea, the fry laving passed out of the river at a rery early age, before eved the nuclear plate and the first scale ring had lecen formed.

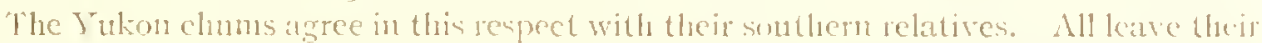

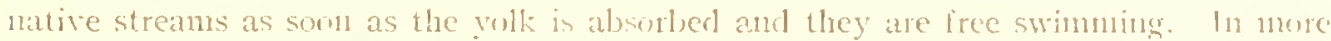

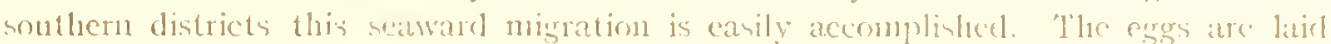
in gravels not far remored from the tides, and the young, when free, eacily drop down with the current to the shore line. The case is less simple with the lukon fisli, many of which have 2 , no miles or more to cover at a period when they atverage only 1 tá inclies long. No information is aroulable concerning the dates on which this migration is effected. Observations further south inclicate a very early descent to the sea in the spring of the year. It is not known, however, to what extent hatching of the egres and development of the yonng on the Inkon are retarded by the rery low temperatures to 
which they are exposed. Crow th during the seaward migration can not be considerable, for none of the material that we have examined indicates the fornation of the scale nucleus while still in the stream.

Growth of this species in the sea seems to proceed with remarkable regularity, with the result that the scales are diagrammatic in their simplicity and seldom afford any dificulty in detemination of age. In the case of the liution race, such uncertainty as may be experienced is concerned with the interpretation of the peripheral region of the scale and is baserl on the fact that the scale margins differ widely in condition annong individuats captured on the same date. It is gencrally recognized that individuals of a given race will vary matcrially in the date on which they begin the rapid growth of the spring after the winter pause. Among the fish captured in Nay or early June in more sontherly wates an occasional individual may inclicate no grow th of the current scason, while others will vary in the number of peripheral wide rings by which the annont of spring growtl may be computed. In the lukon dog salmon, however, this variation at the time they leave their feeding gronnds and enter on their spanuing run is extrene. An necacional fish, as shown by Figne 206 , had begun no new growth of the year, the nargin of the scale being formed by the close-ringed check of the previous winter. Others, as represented in Figure 29f, hat barely inangurated the new growth, which is indicated by two or the wide rings outcicle the winter check. There then follow fairly connpletc series with crer-increasing growth of the season, as shown in figures 297 , 290,295, and 292 , the last damed hatring finished an arerage season's growth for the third year, with the exception of the winter check.

When it is recalled that these dog salnon cnter the lukun in company with the king salmon and that the king salmon lave not in any case made unmistakable growth for the curreil seasnt, the habit of the dog silnum in this regard scents most peculiar. In the earty and midnte parts of the run, to which alone we had access, none of the indivirluats examinerl had begun at winicr check at the nurgin of the scales for the current vent. Whore a marsinal winter check existed, it lad been formed the previons winter and presented no real difficulty in determining age. If the latter part of the rum should be found to contain a group of individuals in which ia check was forning at the scale margin and also another group with scales like Figure 29,3, in which the narginal check belonged to the previons wintcr and no further growth had been registered, a real dificultr might arise in cletemining the age of such individuals. The two sroups wonld show essentially similar scale structure, but one would be one year older than the other. It is not probahie, however, that representatives of these two classes would be found together in any portion of the run. As the season advanced we should expect to fincl extrencly few, if any, that had fatled to produce some new srowth of the vear.

\section{THE SCCKEYE SALMON (Oncorhynchus nerka).}

I few scattering sockeyes (Alaska red salmon) enter the lukon Rirer duing Iuly and early August. In 1919 the Carlisle Paking Co. put up 22 cases of talls and $\dot{b}$ cases of flats of this species and handled a total of about 300 fish. The sockeyes appeared even less numerous in the following year, when only 5 cases, containing about 60 fisl. were packed.

If a permanent colony of red salmon exists in the Yukon, it must ascend to the lakes near the source of the river, but we have nu knowledge that such spawning grounds for this species exist. That individuals ascend the river for long distances is certain, 


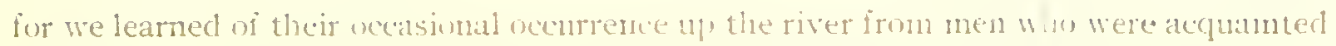
with the different speciess of salmon, and we olsserved one, a male, decidedly pink in color, at Ruby on - lugrust 1.4 . 1920, sume $(1,50$ miles above the mouth of the river.

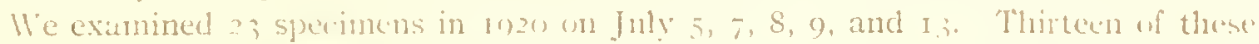

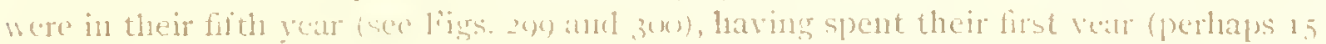

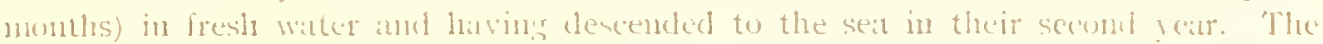
scales exhibit a vigorous frebli-water errowth, followed by three complete rear gecords at sea. A few w these scales, as in figure sor, have a matrginal check, which was

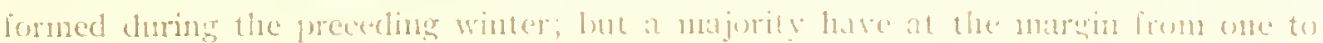
fonr whie rings denoting new erowth o! the year.

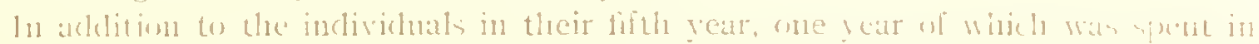

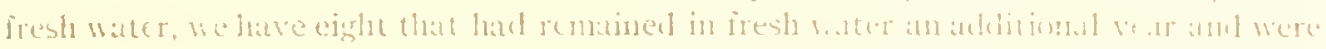

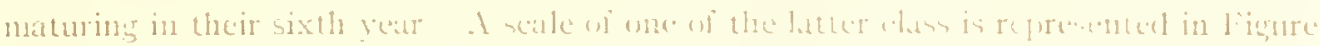

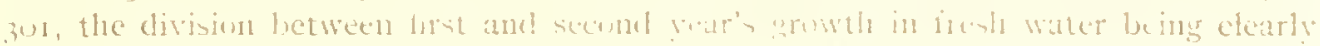

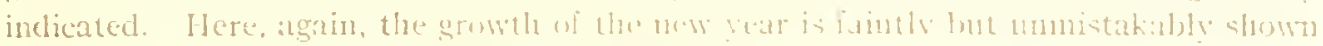
along the amterior lefthand nargin of the wate.

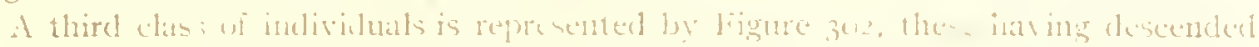
to the seal som after hatching and prior th the githth of the seake. Fhe lwa calnum

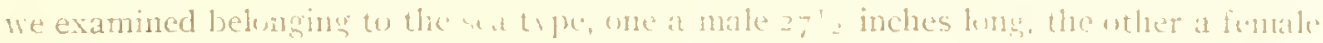

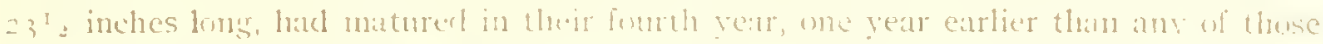
that had lingerec? in fresh watler.

Whether the lubon red sahnon are strays from wome colony to the sonthurard

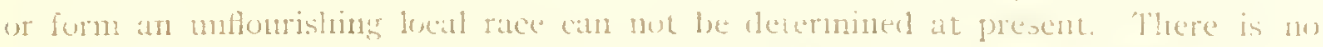
reason to believe that more than wre rate is representer in oner meager mater $\mathrm{i}_{1}$.

\section{THE COHO SALMON Oncorhynchus kisutch.}

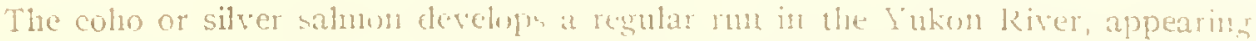
sparingly at the mouth of the river in the latter part of Jaly, but the run dhes not whow

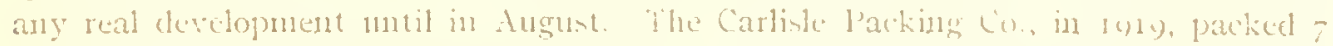

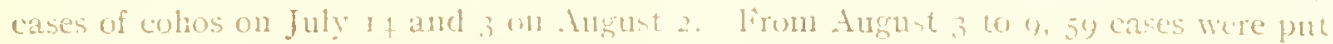

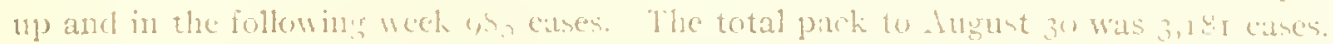

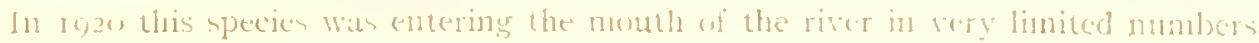

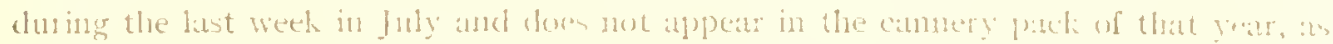

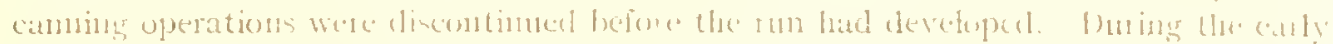
hatl of August, between the month of the river and lanana, we fond at all hivhing

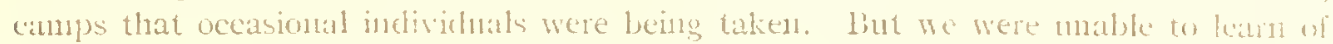
its oceurrence in the main river athove Tanania. It is well attested that the species enters the Tanani and spaws in one or more tributaries of the Kantisma. Ilow generally it is distributed over the basin we were unable to ascertais.

When the coho enters the river it is a perfecty symmetricul fish, with brilliant silvery color, but in traversing the lower portion of the river it takes on an red livery, and the males assume at the same time the characteristic snub-nosch appearance of the breeding fish, the lipjer jaw becoming blunty hooked orer the lower in a mannuer characteristic of this species.

Scales of Yukron enhess are 1 epresented in lighures 286 to 289 . Is in all other colon colonies that we have exumined, thuse from the Vuhom are always in their seond years (i) $11^{-0}-2 \cdot 2$ - 
of sea growth when captured." Outside the narrow-ringed central area, which records the life in fresh water, we invarially find in this species a vigorous summer growth, succeeded by a well-marked winter check, and this in turn followed by an extensive marginal growth of widely-spaced rings, which measure the growth of the eurrent season of capture.

In the southern part of its range, where the coho uniformly spends one season in fresh water beiore nigrating seawards, the spawning run (aside from a few male grilse in their second year) consists exclusively of 3-year fish. As we proceed northward, however, we enconnter individuals that have tarried two years in the streams and are maturing in their fourth year. These are more abundant in the Yukon than in any other stream we have examined. Our small collection of 31 individuals comprises I 2 that have spent one year in a stream and are 3 years old (see Figs. 286 and 287) and i 8 that renained two years in fresh water and are in their fourth year (Fig. 288). If the customary proportions are shown in this collection, some 60 per cent of the yonng spend two years in fresh water. One indiridnal of our collection (Fig. 289) had apparently spent three years in the river and was maturing in its fifth year. The number of individuals at out disposal is too small in the various elasses to give reliable averages. Six 3-year males arerage 23.8 inches in length (middle caudal rays included, as in all our measurements); four 3 -year females, 24.6 inches. Eleven t-year males (two years in fresh water) arerage 24.5 inches; six tyear females, 25.3 inches. As males are consistently lurger than females among Pacifie salmon, we have additional reason for distrusting the adequacy of the aljove figures. The 5-year male (three years in stream) is 23 inches long.

\section{THE HUMPBACK SALMON (Oncorhynchus gorbuscha).}

Scattering humpbacks enter the river in July and August and are then so near their spawning time that they would be mable to ascend the strean for any considerable distunce. We observed one ripe male at Andreafski on Angust 3 and were unable to learn of the occurrence of the species beyond that point.

The individuals observed were all small and without value, having of ten liquid milt and partly free eggs. Four specimens measured from 20 to 22 inches in length and weighed from + to 5 pounds. As in the case of all other humpbacks that have been exanined for age, these were in their second year and had proceeded to sea as soon as free swimming, their scales registering none but sea growth. The small size was doubtless due in part to the fact that they were maturing so early in the season, thus greatly limiting the growth of the second year. The seales all inclieated this history, for the area representing growth of the second year was narrow and contained a partial check at the margin.

"We do not here include the few mule grilse, which 11 tmore houthern diutricts mature during lite first jear at sea. 

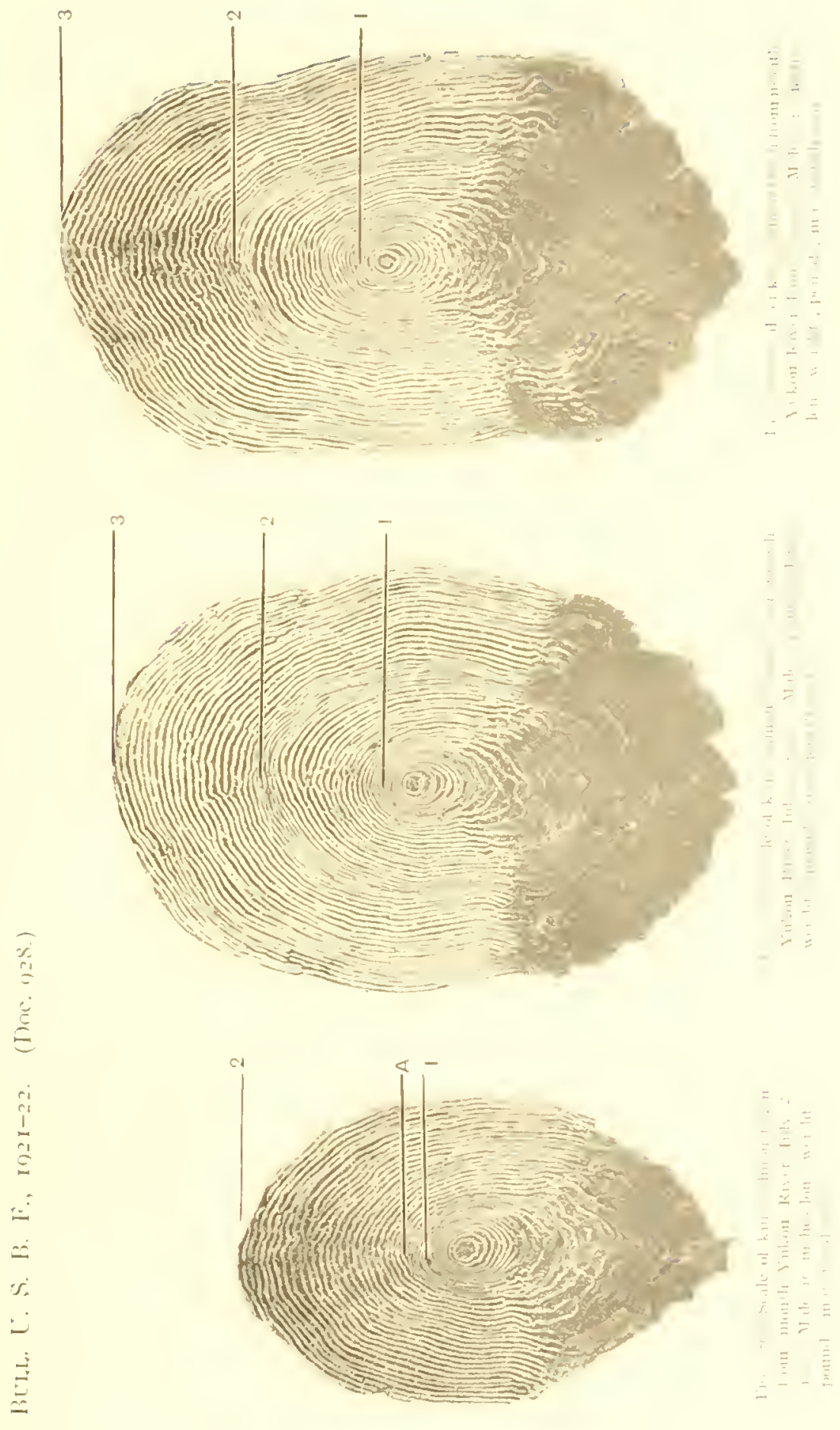


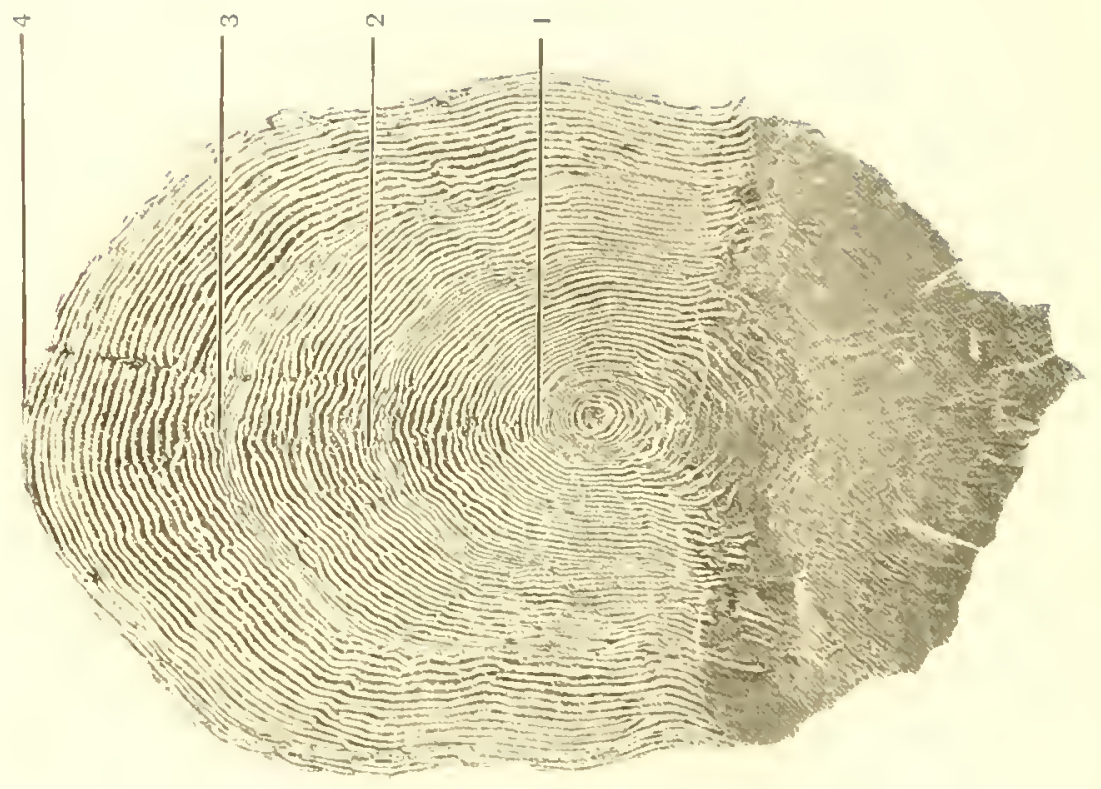

烈

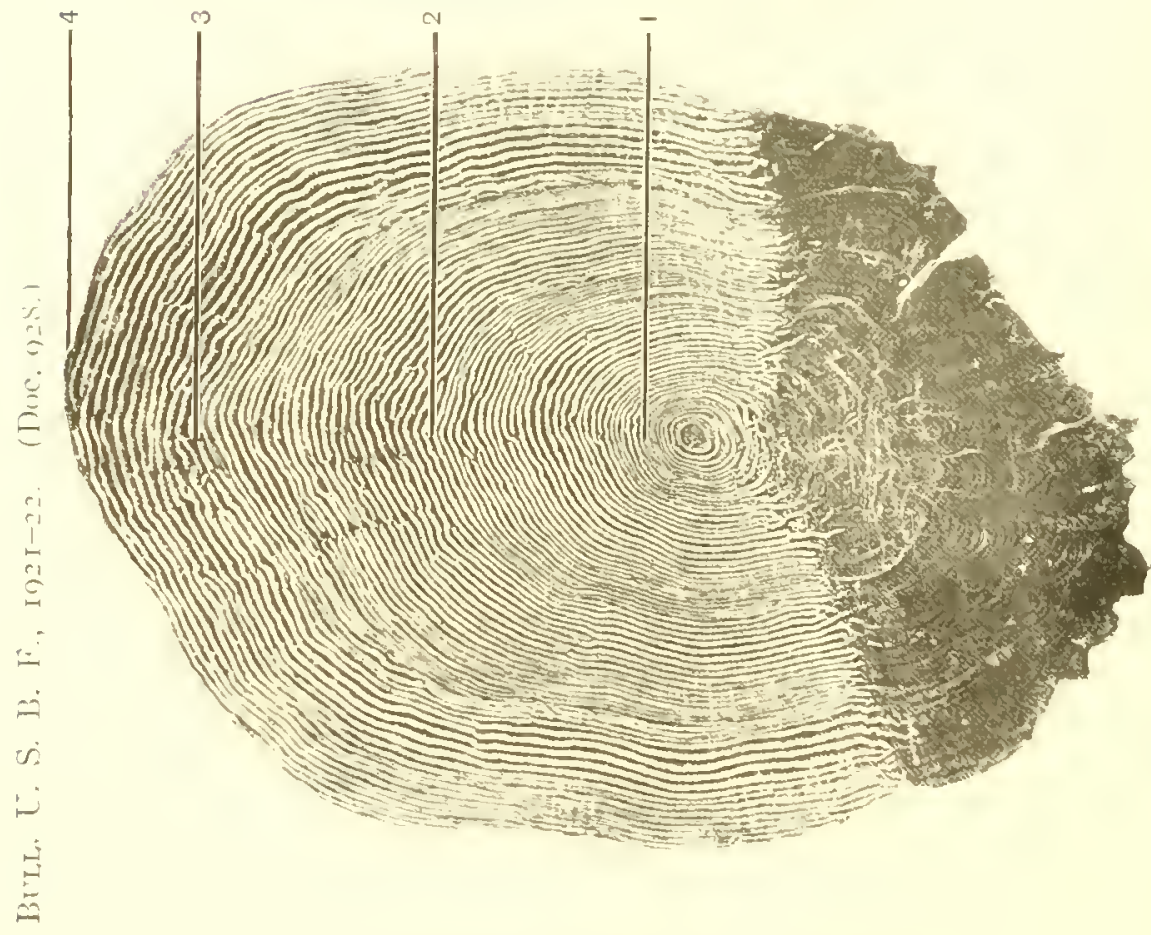



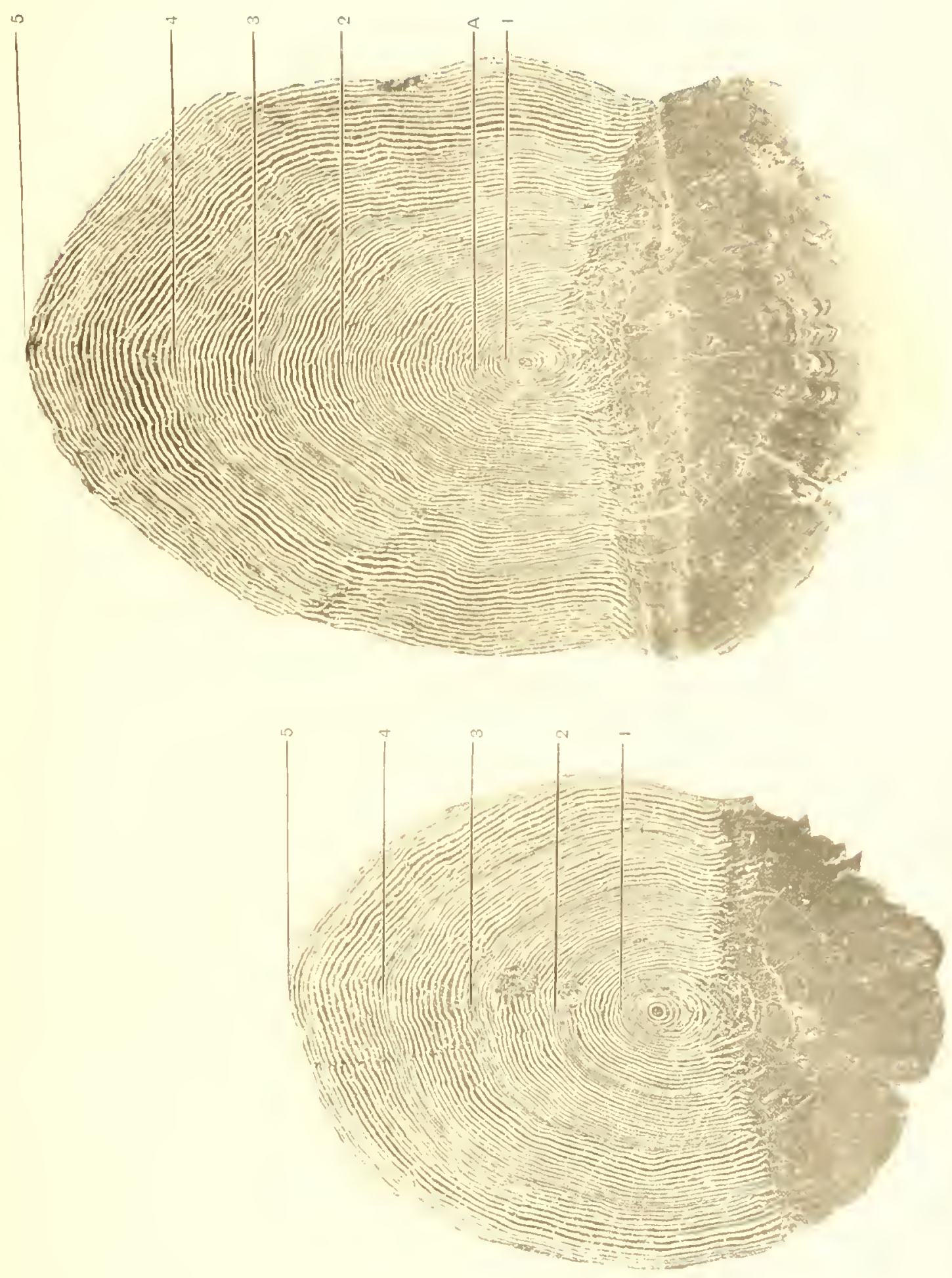


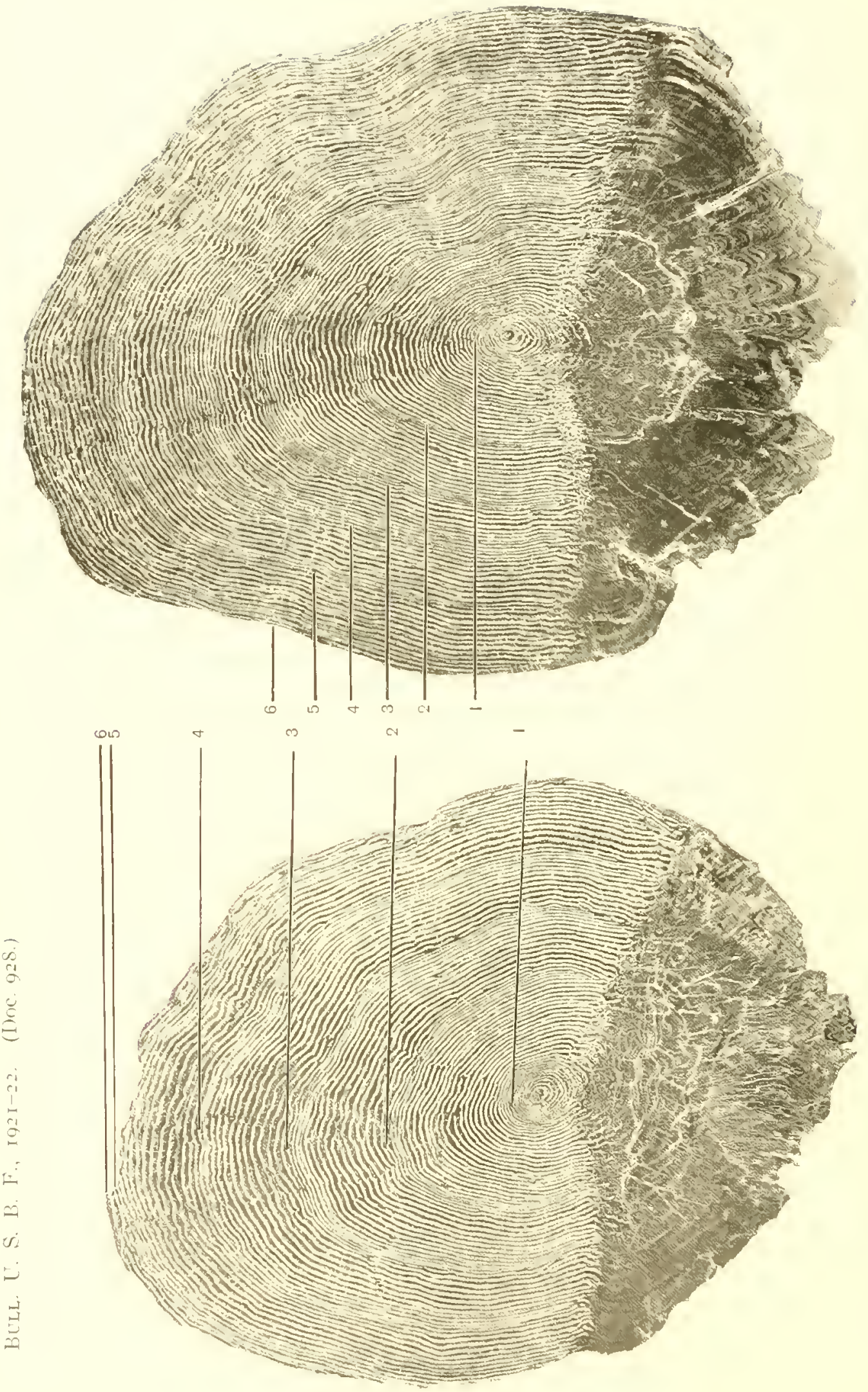




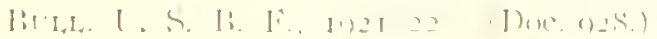

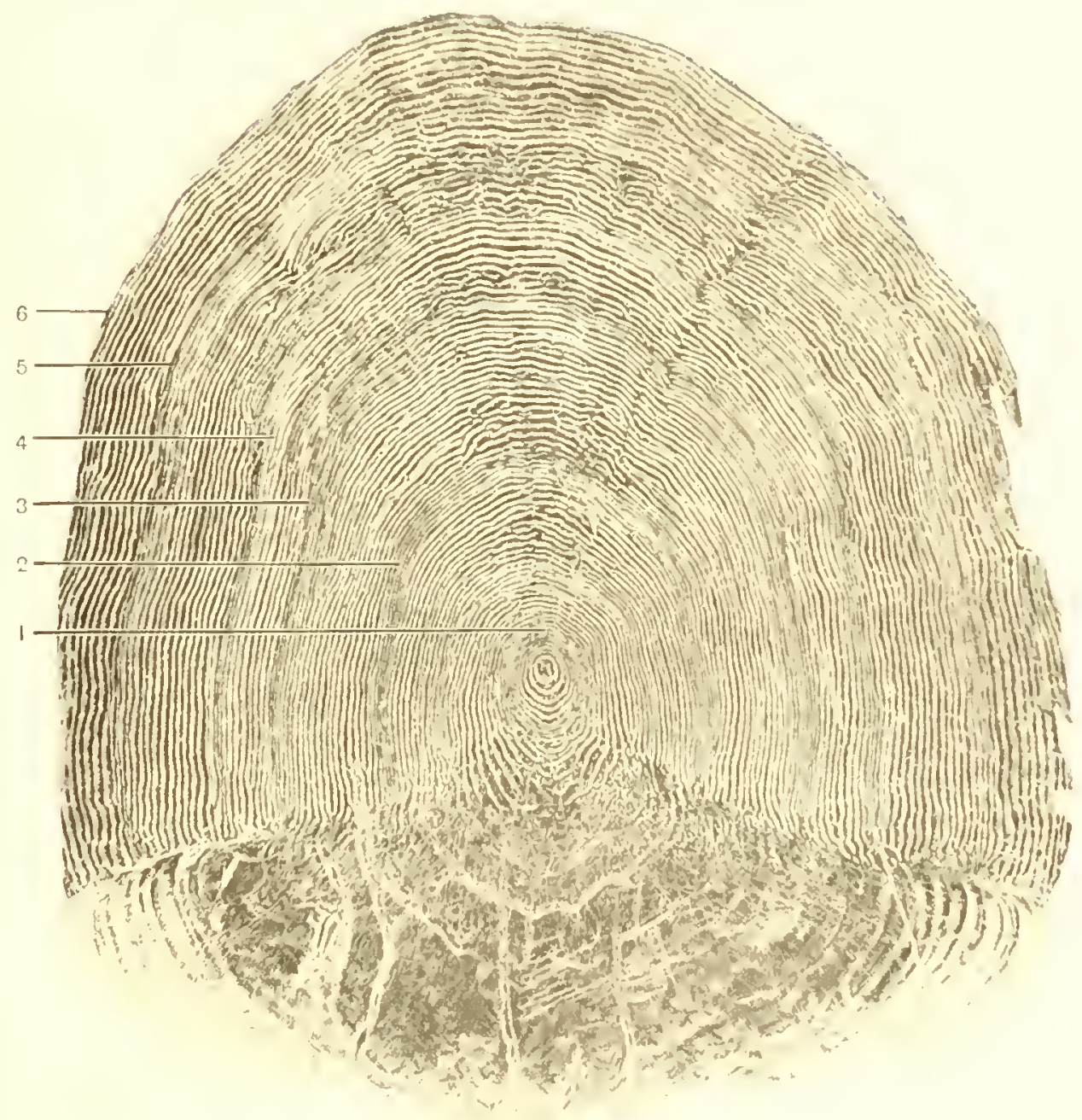

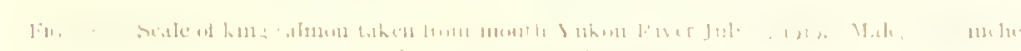



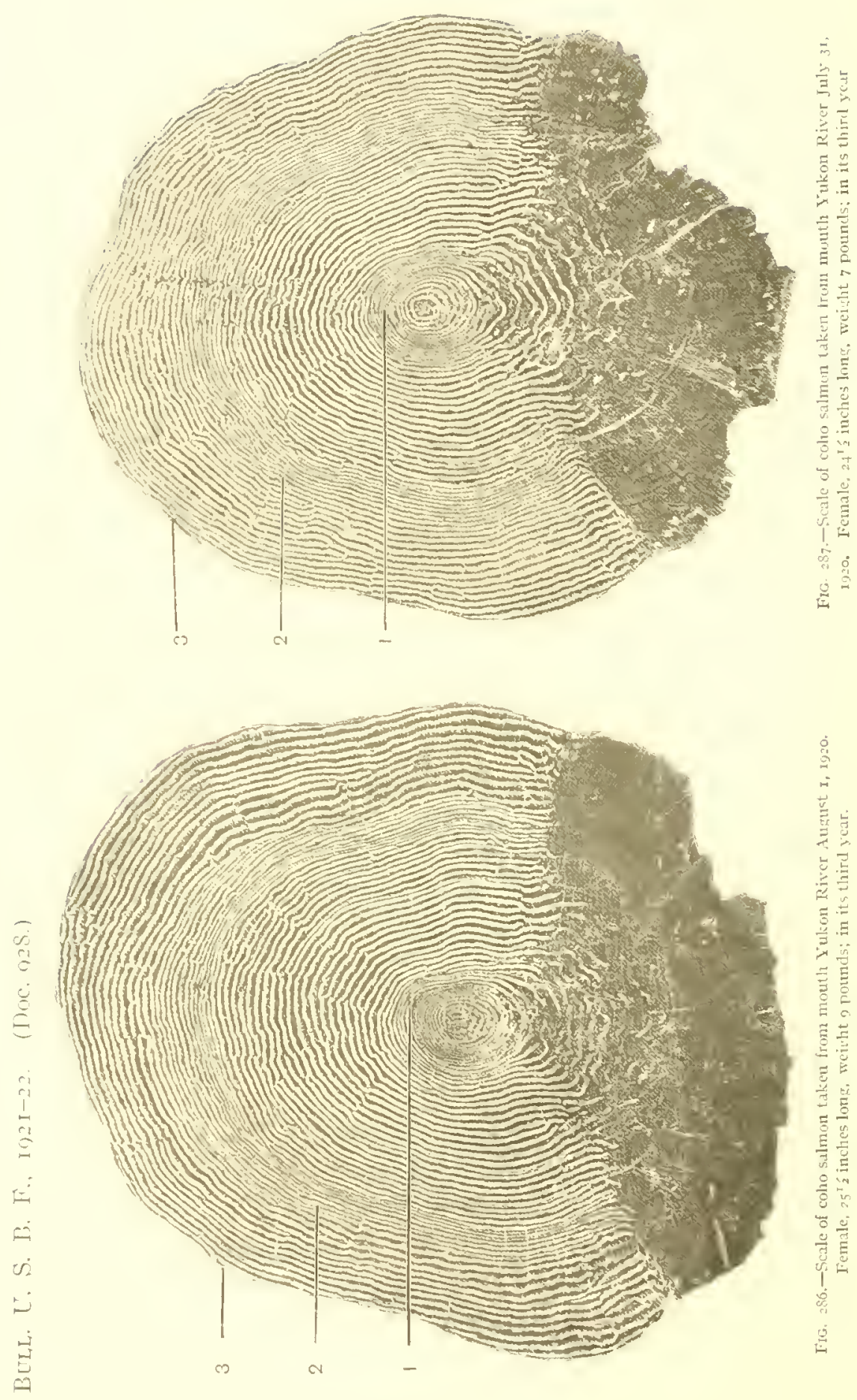

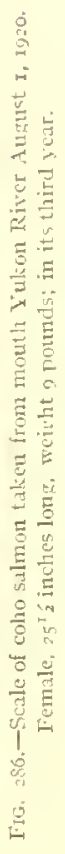



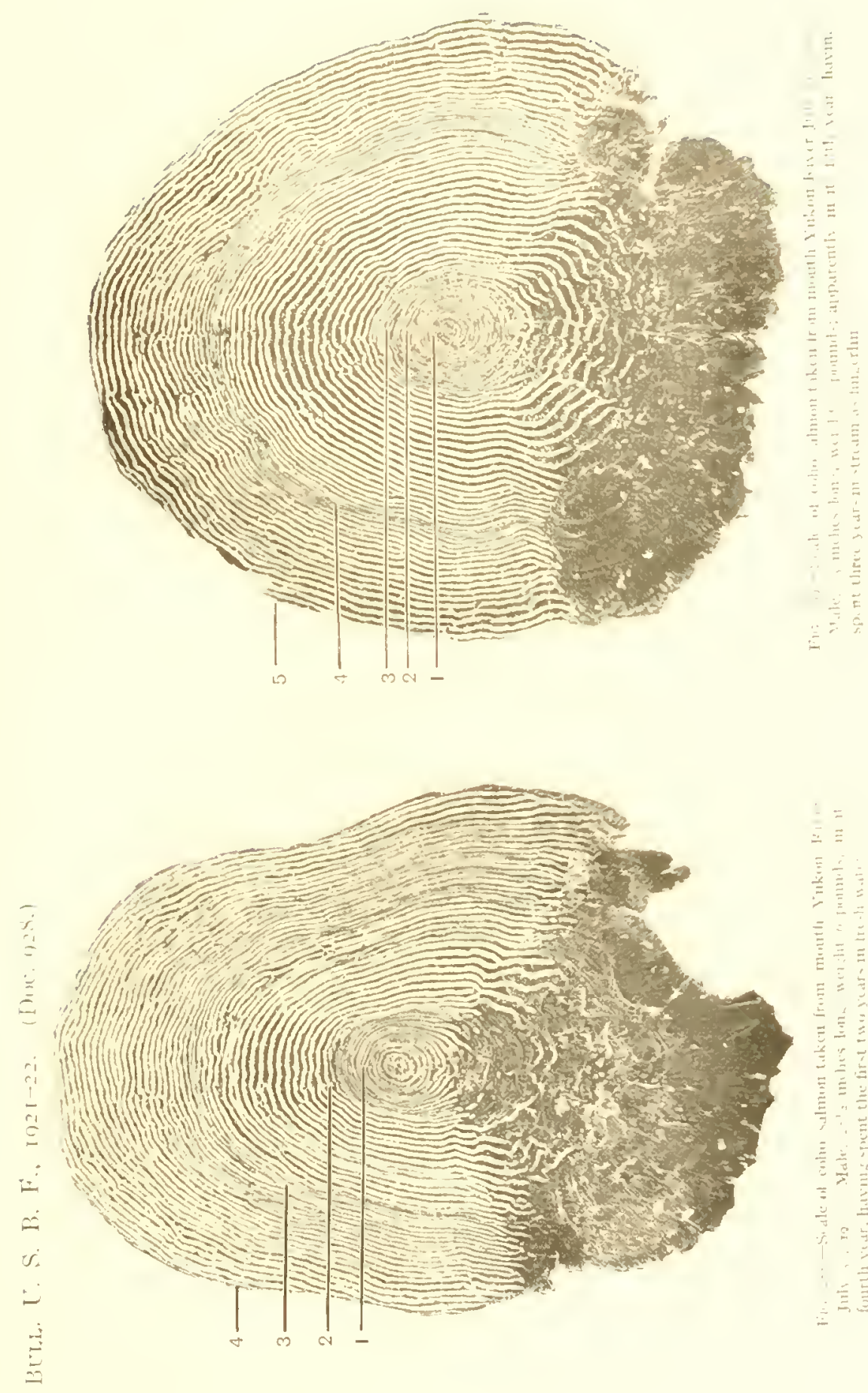


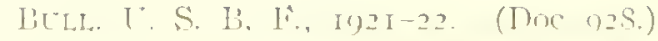

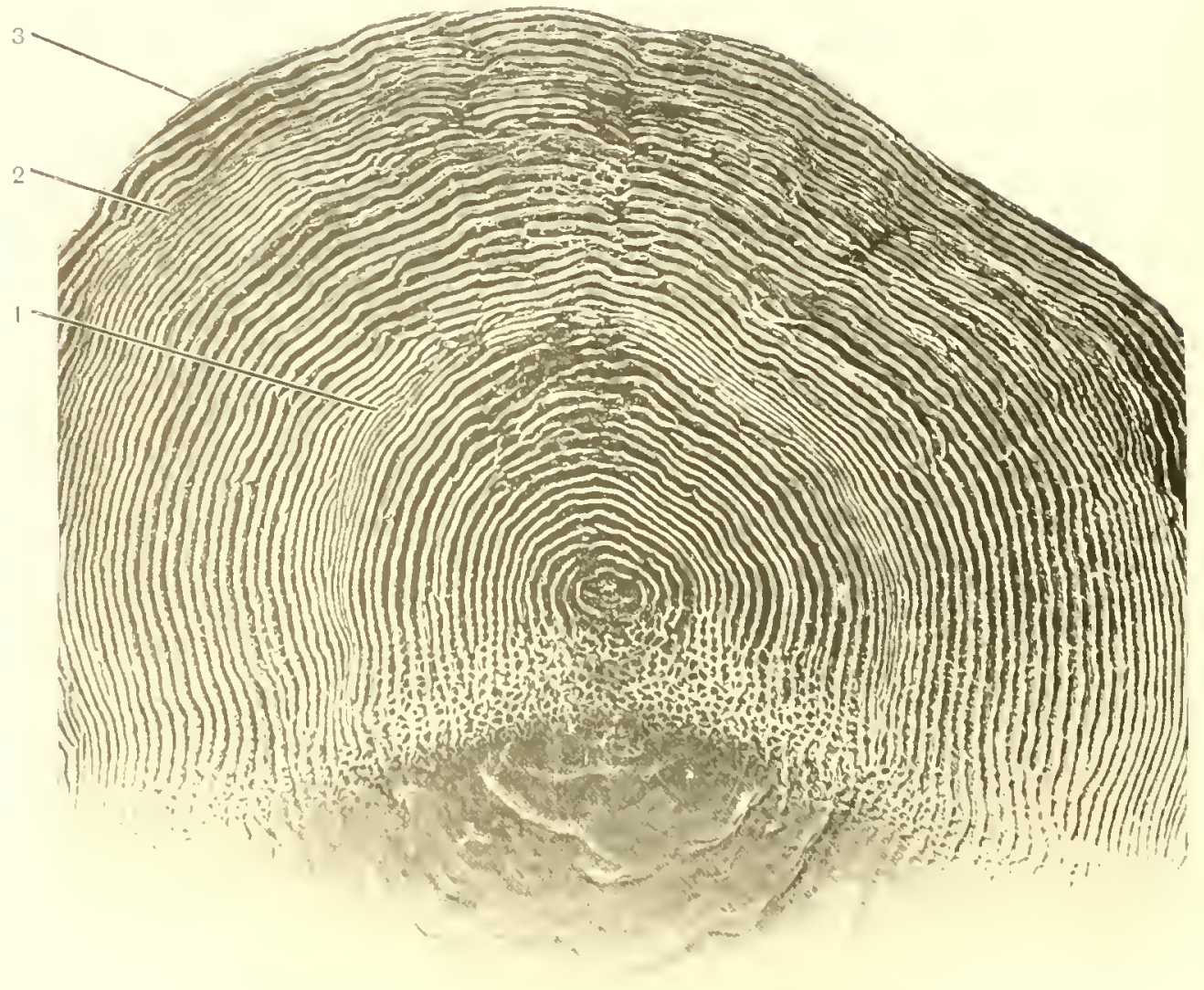




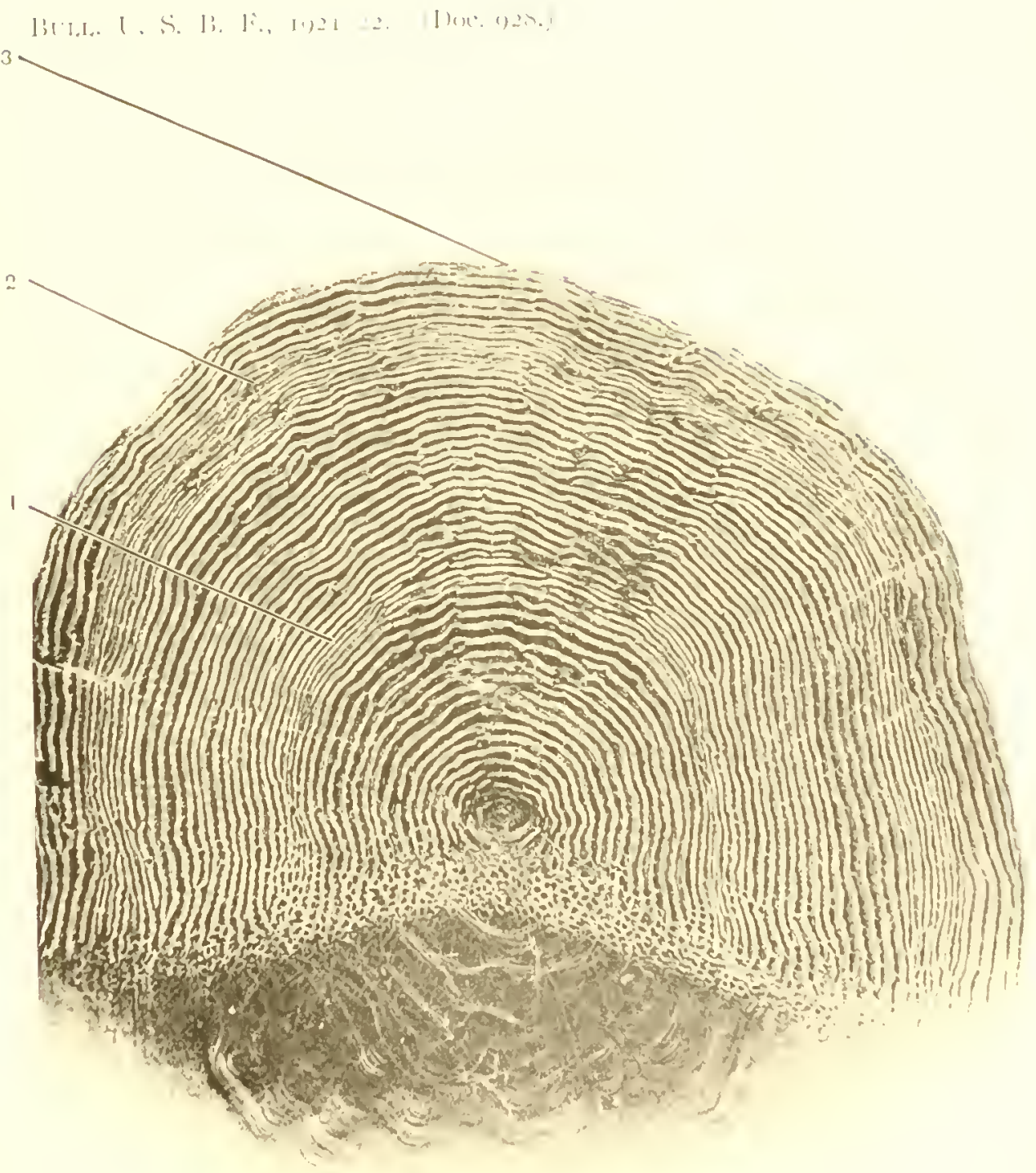




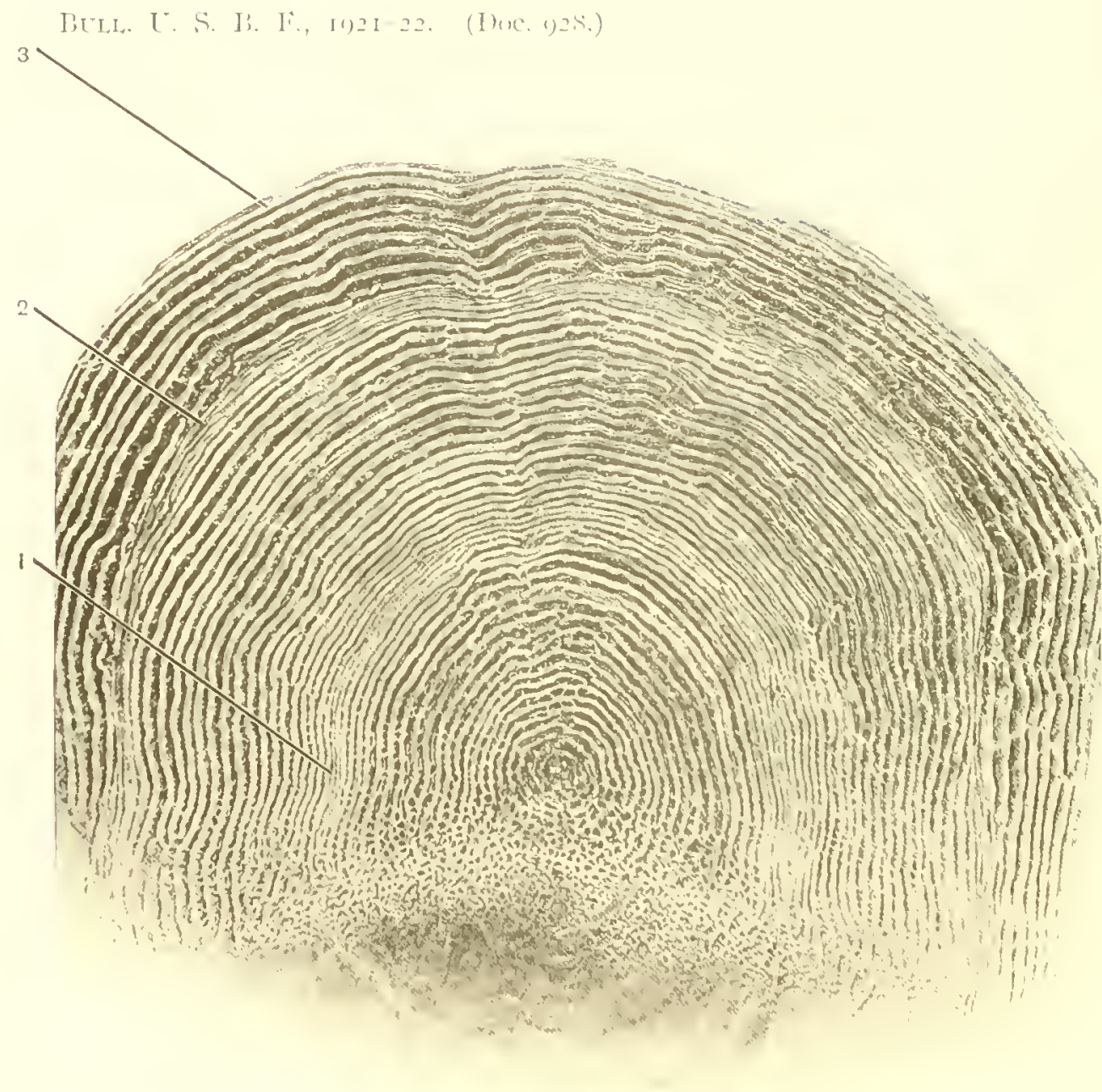




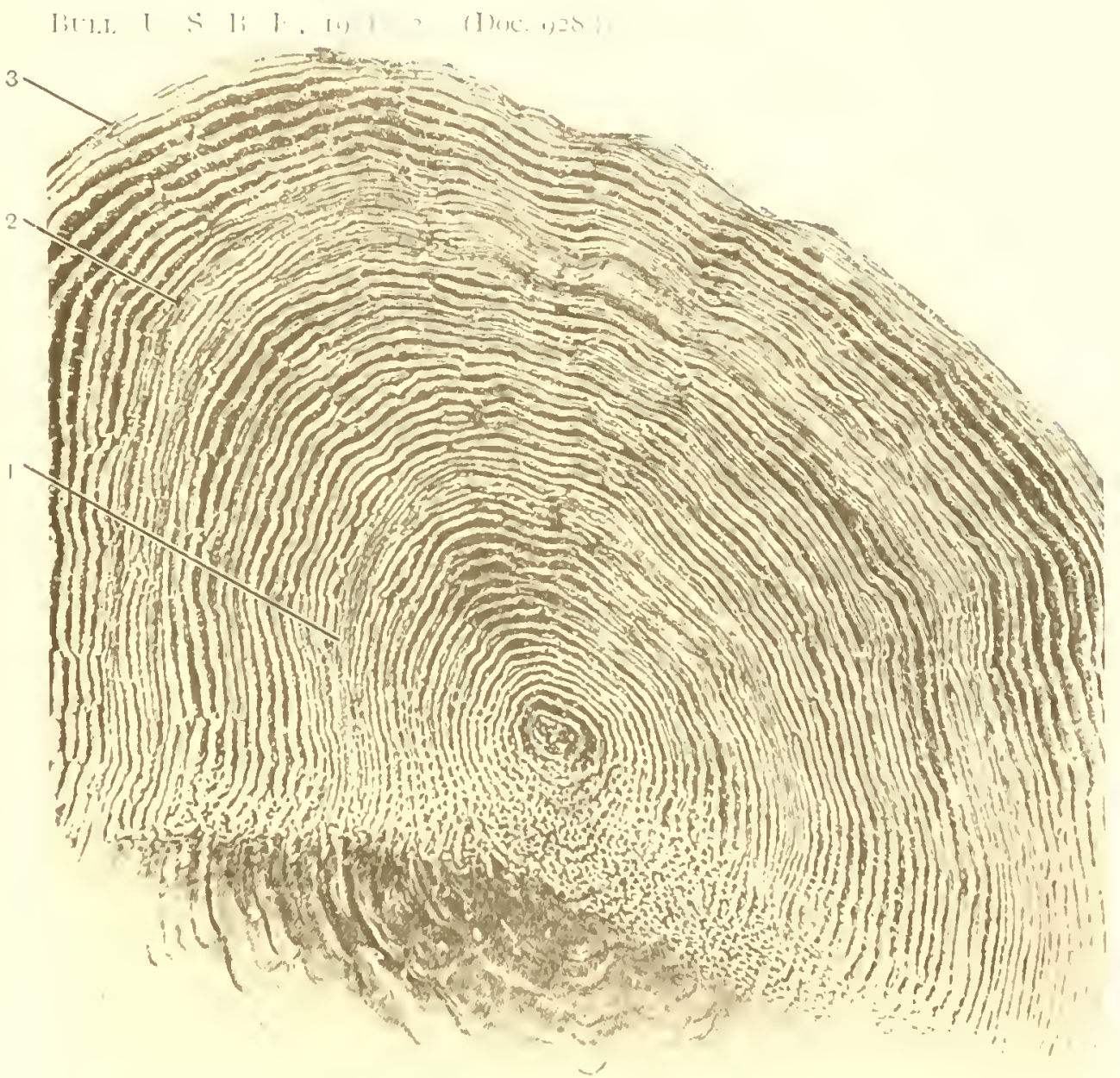




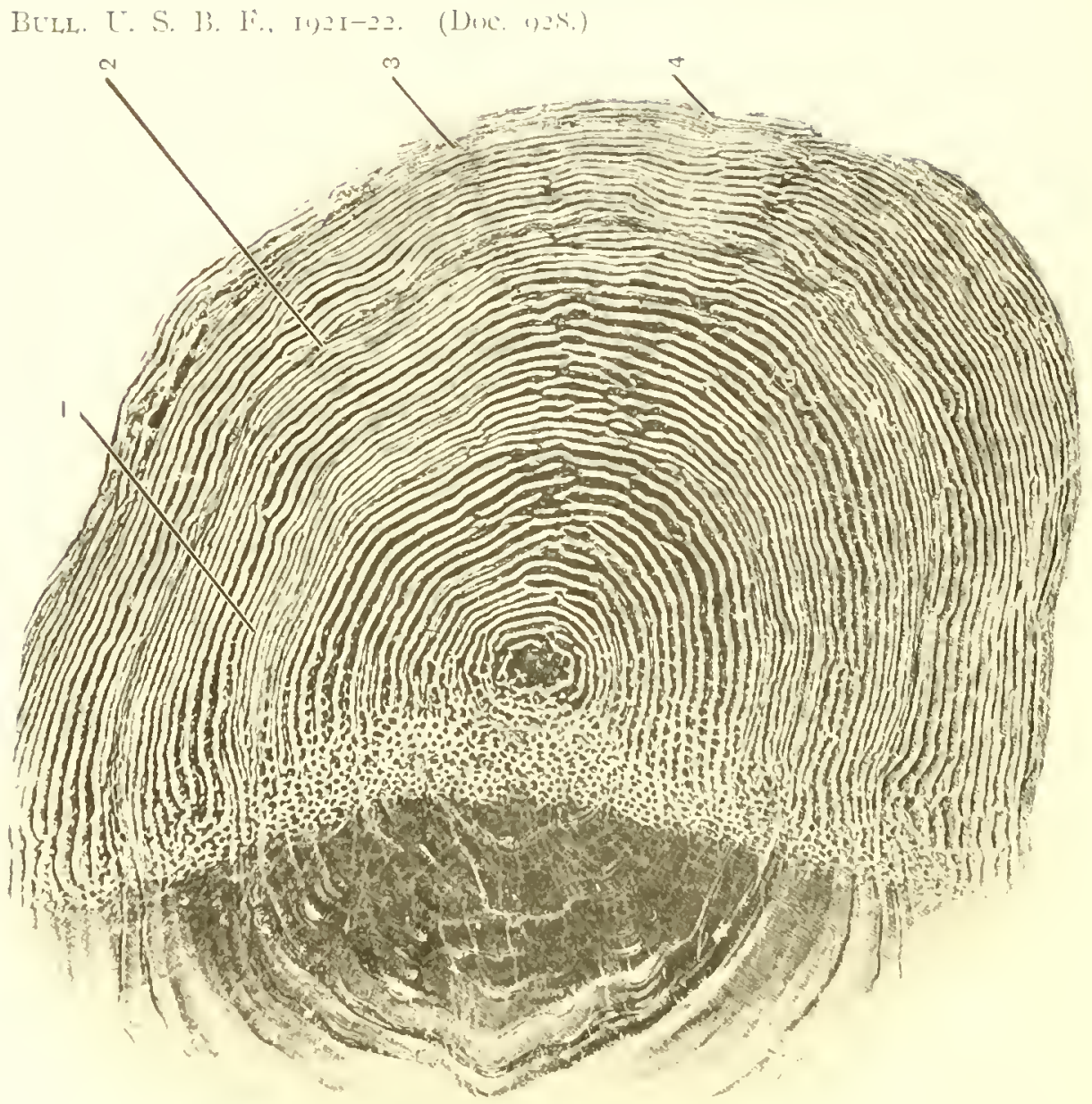




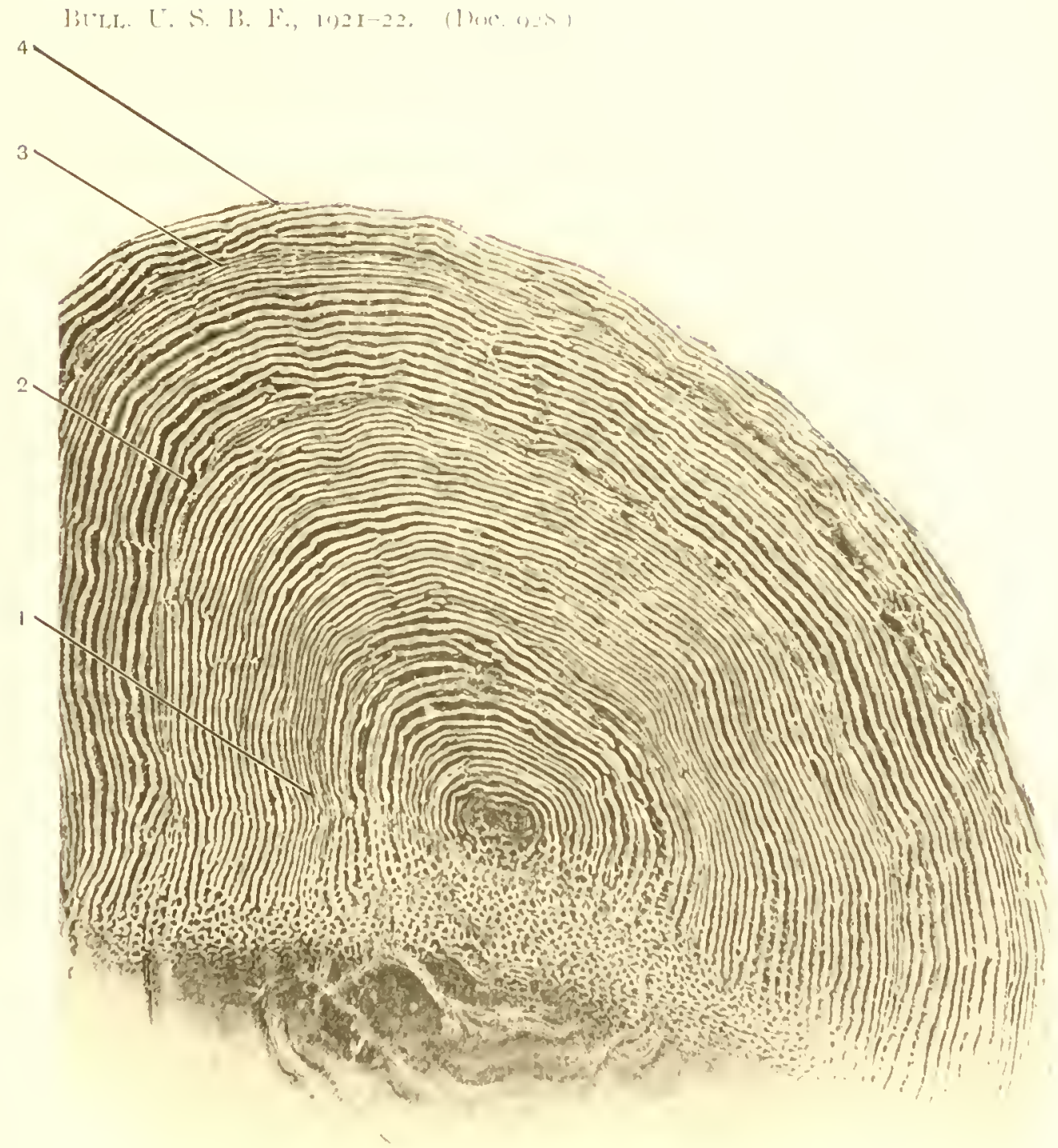




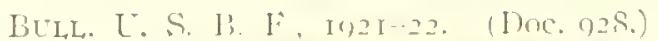

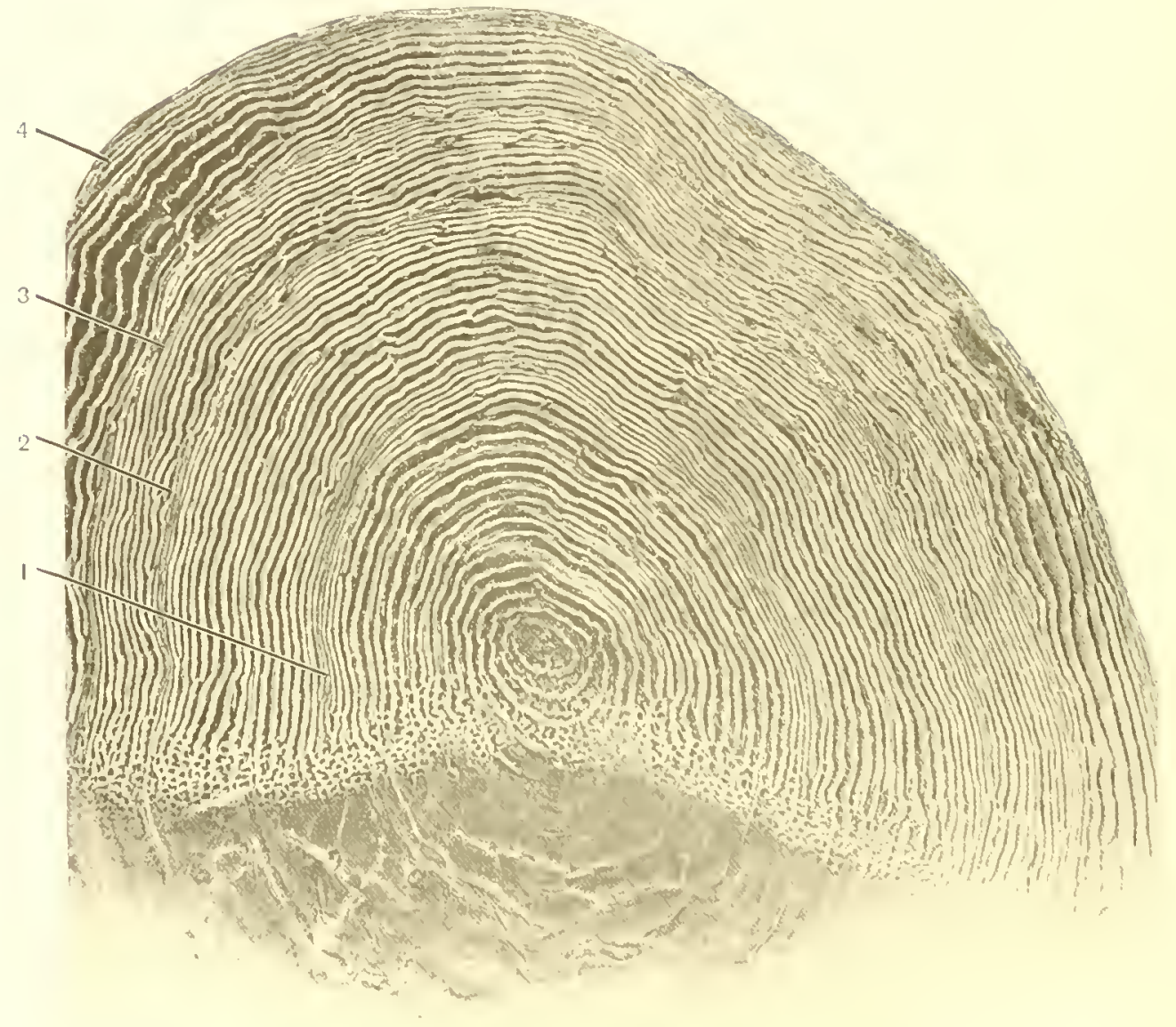

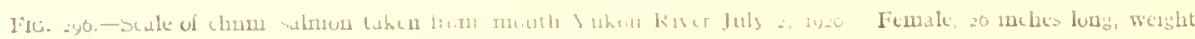




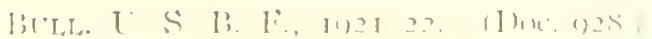

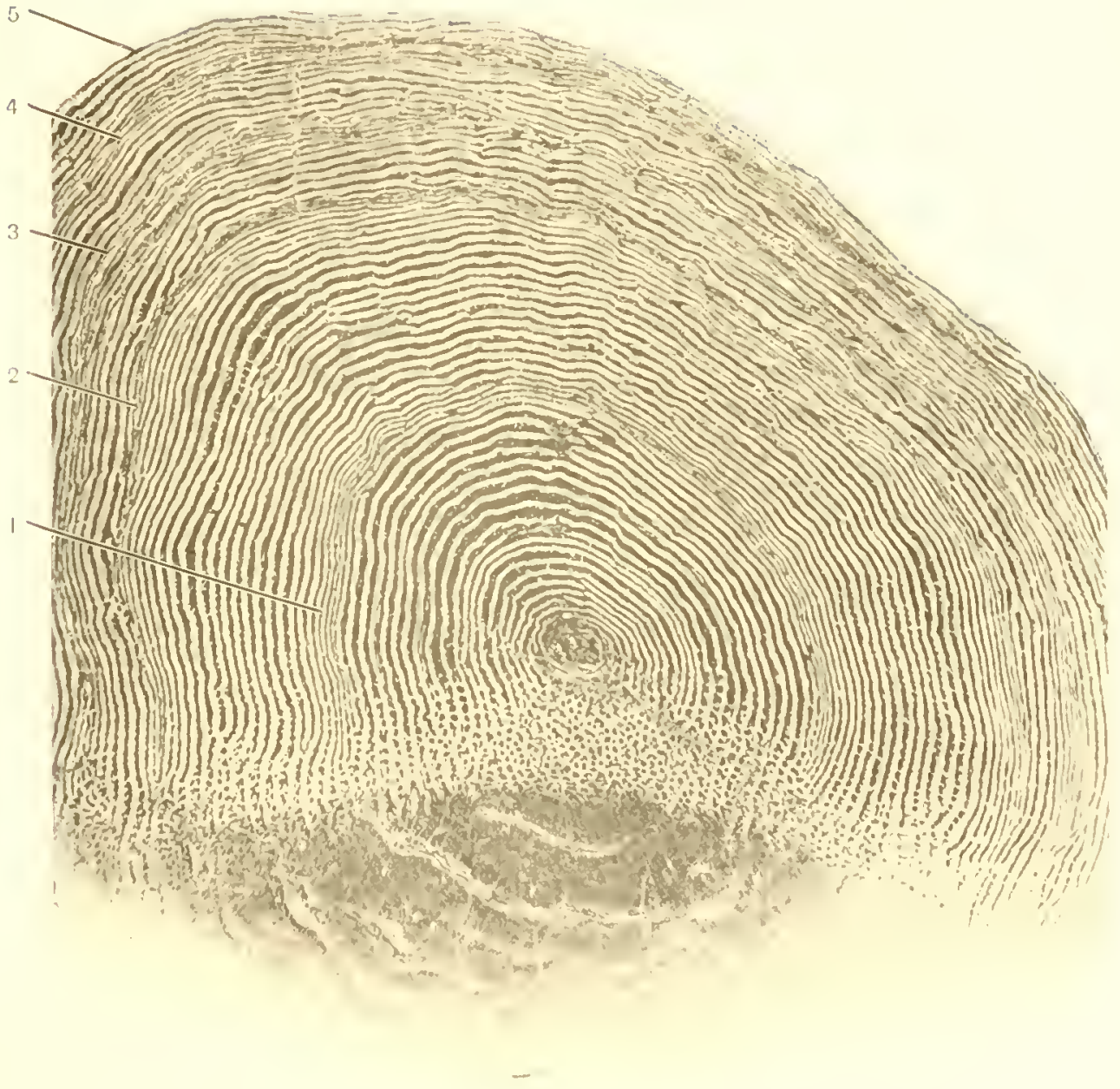




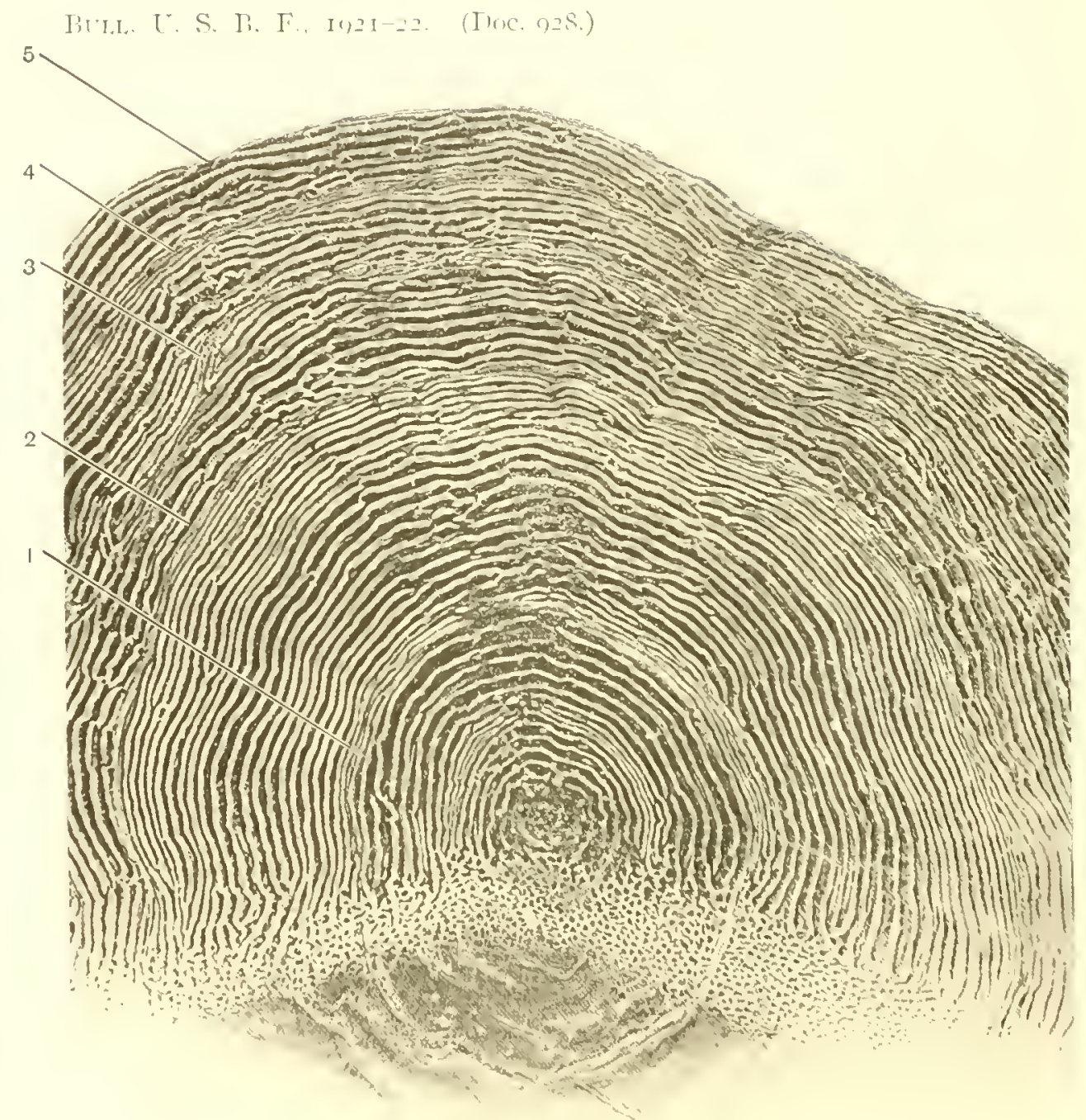



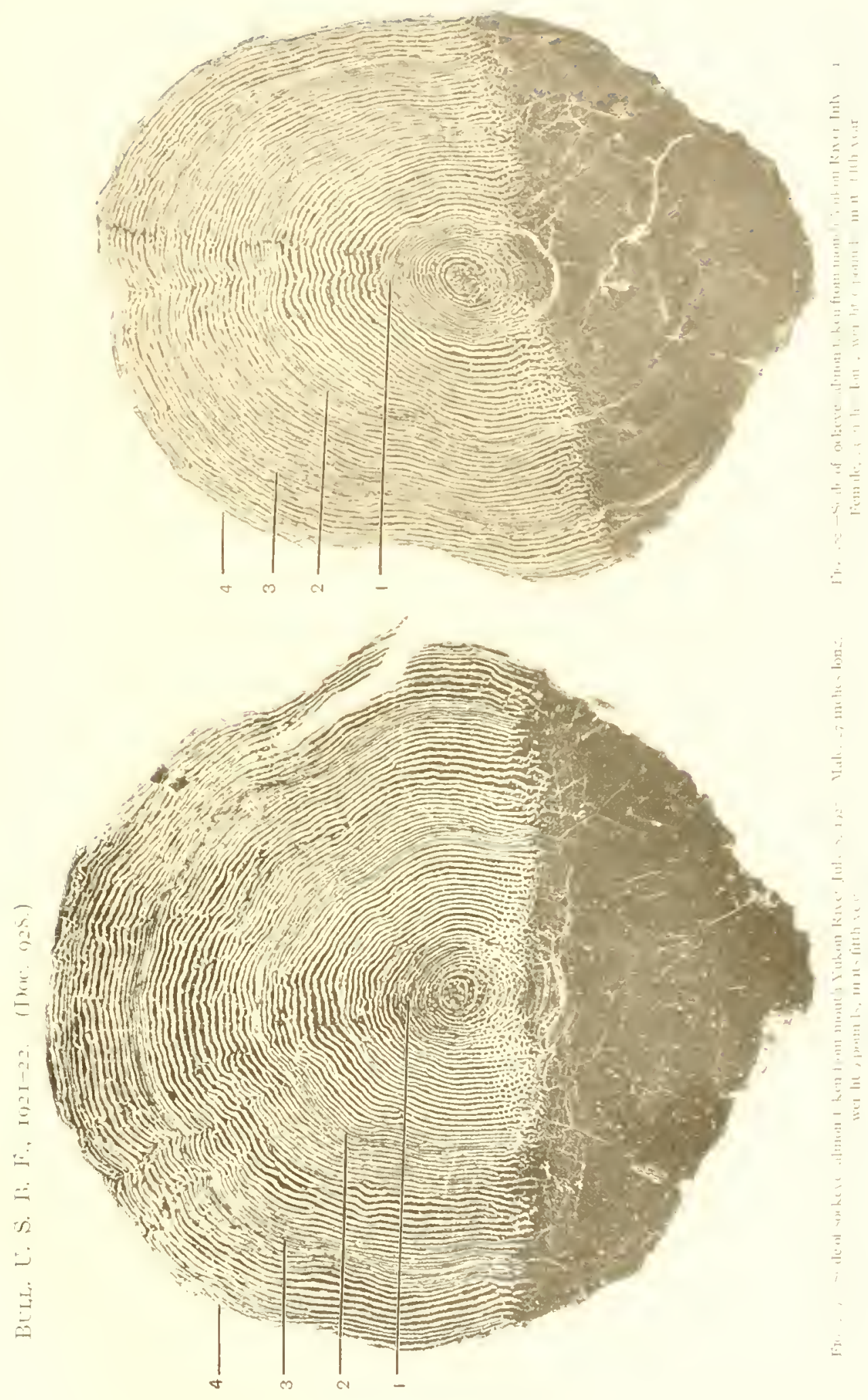


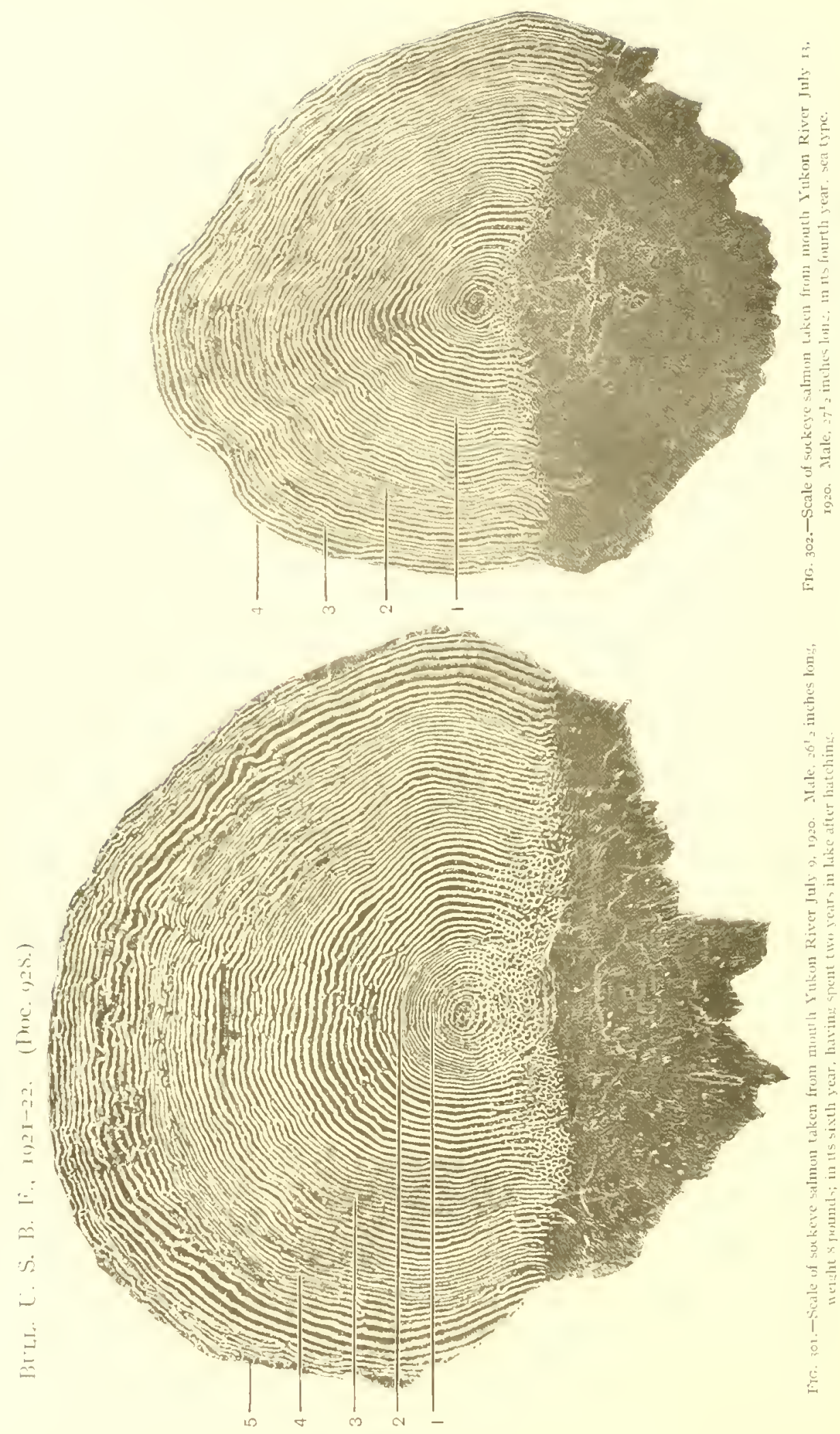






